\title{
Using GIS to examine biogeographic and macroevolutionary patterns in some late Paleozoic cephalopods from the North American Midcontinent Sea
}

\author{
Kayla M Kolis ${ }^{1}$, Bruce S Lieberman ${ }^{\text {Corresp. 1, } 2}$ \\ 1 Biodiversity Institute, University of Kansas, Lawrence, Kansas, United States of America \\ 2 Department of Ecology \& Evolutionary Biology, University of Kansas, Lawrence, Kansas, United States of America \\ Corresponding Author: Bruce S Lieberman \\ Email address: blieber@ku.edu
}

Geographic range is an important macroevolutionary parameter frequently considered in paleontological studies as species' distributions and range sizes are determined by a variety of biotic and abiotic factors well known to affect the differential birth and death of species. Thus, considering how distributions and range sizes fluctuate over time can provide important insight into evolutionary dynamics. This study uses Geographic Information Systems (GIS) and analyses of evolutionary rates to examine how in some species within the Cephalopoda, an important pelagic clade, geographic range size and rates of speciation and extinction changed throughout the Pennsylvanian and early Permian in the North American Midcontinent Sea. This period is particularly interesting for biogeographic and evolutionary studies because it is characterized by repetitive interglacial-glacial cycles, a global transition from an icehouse to a greenhouse climate during the Late Paleozoic Ice Age, and decelerated macroevolutionary dynamics, i.e. low speciation and extinction rates. The analyses presented herein indicate that cephalopod species diversity was not completely static and actually fluctuated throughout the Pennsylvanian and early Permian, matching findings from other studies. However, contrary to some other studies, the mean geographic ranges of cephalopod species did not change significantly through time, despite numerous climate oscillations; further, geographic range size did not correlate with rates of speciation and extinction. These results suggest that pelagic organisms may have responded differently to late Paleozoic climate changes than benthic organisms, although additional consideration of this issue is needed. Finally, these results indicate that, at least in the case of cephalopods, macroevolution during the late Paleozoic was more dynamic than previously characterized, and patterns may have varied across different clades during this interval. 


\section{Using GIS to Examine Biogeographic and Macroevolutionary}

\section{2 patterns in some Late Paleozoic Cephalopods from the North}

\section{American Midcontinent Sea}

4

5 Kayla M. Kolis ${ }^{1}$ and Bruce S. Lieberman ${ }^{1,2}$

$6 \quad{ }^{1}$ Biodiversity Institute, University of Kansas, Lawrence, Kansas 66045, U. S. A.

$7 \quad{ }^{2}$ Department of Ecology \& Evolutionary Biology, University of Kansas, Lawrence, Kansas

$8 \quad 66045$, U. S. A.

10 Corresponding author:

11 Bruce S. Lieberman

12

13 E-mail address: blieber@ku.edu 


\section{Abstract}

25 Geographic range is an important macroevolutionary parameter frequently considered in paleontological studies as species' distributions and range sizes are determined by a variety of biotic and abiotic factors well known to affect the differential birth and death of species. Thus, considering how distributions and range sizes fluctuate over time can provide important insight into evolutionary dynamics. This study uses Geographic Information Systems (GIS) and analyses of evolutionary rates to examine how in some species within the Cephalopoda, an important

31 pelagic clade, geographic range size and rates of speciation and extinction changed throughout

32 the Pennsylvanian and early Permian in the North American Midcontinent Sea. This period is particularly interesting for biogeographic and evolutionary studies because it is characterized by

34 repetitive interglacial-glacial cycles, a global transition from an icehouse to a greenhouse climate 35 during the Late Paleozoic Ice Age, and decelerated macroevolutionary dynamics, i.e. low 36 speciation and extinction rates.

37 The analyses presented herein indicate that cephalopod species diversity was not completely static and actually fluctuated throughout the Pennsylvanian and early Permian, matching findings

39 from other studies. However, contrary to some other studies, the mean geographic ranges of cephalopod species did not change significantly through time, despite numerous climate oscillations; further, geographic range size did not correlate with rates of speciation and extinction. These results suggest that pelagic organisms may have responded differently to late is needed. Finally, these results indicate that, at least in the case of cephalopods, macroevolution 
45 during the late Paleozoic was more dynamic than previously characterized, and patterns may

46 have varied across different clades during this interval.

\section{Introduction}

Much work has focused on the relationship between geographic range size and rates of speciation and extinction (e.g., Vrba, 1980; Jablonski, 1986; Eldredge, 1989; Stanley, 1990; Lieberman, 2000; Jablonski \& Roy, 2003; Rode \& Lieberman, 2004, 2005; Kiessling \& Aberhan, 2007; Liow, 2007; Payne \& Finnegan, 2007; Abe \& Lieberman, 2009; Stigall, 2010; Myers \& Saupe, 2013; Myers, MacKenzie, \& Lieberman, 2013; Dunhill \& Wills, 2015; Jablonski \& Hunt, 2015; Orzechowski et al., 2015; Saupe et al., 2015; Castiglione et al., 2017; Pie \& Meyer, 2017; Simões et al., 2016; Lam, Stigall, \& Matzke, 2018; Schneider, 2018). Furthermore, the use of Geographic Information Systems (GIS) has greatly facilitated investigations into this macroevolutionary relationship (Stigall \& Lieberman, 2006; Hendricks, Lieberman, \& Stigall, 2008; Dunhill, 2012; Myers, MacKenzie, \& Lieberman, 2013; Dunhill \& Wills, 2015; Lieberman \& Kimmig, 2018). Here, we focus on how geographic range size and rates of speciation and extinction changed throughout the Pennsylvanian and early Permian in the North American Midcontinent Sea in the Cephalopoda, an important clade of pelagic invertebrates (Kullmann, 1983, 1985; House, 1985; Becker \& Kullman, 1996; Landman, Tanabe, \& Davis, 1996; Wiedmann \& Kullmann, 1996; Monnet, De Baets, \& C. Klug, 2011; Korn \& Klug, 2012; Klug et al., 2015; Korn, Klug, \& Walton, 2015), using GIS. This time interval is particularly interesting for biogeographic and evolutionary analysis because it is characterized by repetitive glacial-interglacial cycles, a global transition from an icehouse to greenhouse climate

67 during the Late Paleozoic Ice Age (LPIA) (Montañez \& Poulsen, 2013). Further, it is generally 
68 considered a time of sluggish macroevolutionary dynamics, i.e. low speciation and extinction

69 rates and low degrees of faunal turnover, that have been demonstrated in studies of other marine

70 invertebrate taxa (Sepkoski, 1998; Stanley \& Powell, 2003; Bonelli \& Patzkowsky, 2011).

71 However, Ramsbottom (1981), Kullmann (1985), Becker \& Kullmann (1996), and Wiedmann \&

72 Kullmann (1996) did cogently argue that this was not the case for cephalopods. More recently,

73 Balseiro (2016) did document the existence of some profound evolutionary turnover in bivalves

74 and brachiopods over the course of this interval in regions closer to the ice sheets, such as

75 present-day western Argentina. Furthermore, Segessenman \& Kammer (2018) showed that

76 advanced cladid crinoids do display elevated rates of evolution and turnover during this time

77 interval (although three other subclasses of crinoids do show subdued evolutionary rates), and

78 fusulinid foraminifera also fit the pattern shown in the advanced cladids (Groves \& Lee, 2008;

79 Groves \& Yue, 2009; Segessenman \& Kammer, 2018).

80

81 There have been a variety of hypotheses proposed for the postulated decelerated

82 macroevolutionary dynamics (albeit not necessarily in cephalopods) of the LPIA. Some studies

83 contend that this pattern is a result of environmental changes linked to glacial cycling while

84 others point to tectonic activity (Stanley \& Powell, 2003; Powell, 2005; Fielding, Frank, \&

85 Isbell, 2008; DiMichele et al., 2009; Falcon-Lang \& DiMichele, 2010; Bonelli and Patzkowsky,

86 2011; Cecil, DiMichele, \& Elrick, 2014; Segessenman \& Kammer, 2018). To date, many of the

87 more recent studies focusing on the macroevolutionary dynamics of the LPIA have concentrated

88 on benthic marine invertebrates (e.g., Stanley \& Powell, 2003; Powell, 2007; Bonelli \&

89 Patzkowsky, 2011; Balseiro, 2016; Segessenman \& Kammer, 2018) as they are highly diverse

90 and very abundant. However, it is valuable to also investigate evolutionary patterns in pelagic 
91 marine invertebrates as these are also diverse and abundant organisms in late Paleozoic marine

92 ecosystems (Landman, Tanabe, \& Davis, 1996; Monnet, De Baets, \& Klug, 2011; Klug et al.,

93 2015; Korn, Klug, \& Walton, 2015). In particular, given the significant role that geographic

94 factors play in speciation (Mayr, 1942; Eldredge \& Gould, 1972; Jablonski, 1986; Brooks \&

95 McLennan, 1991; Wiley \& Lieberman, 2011; Jablonski \& Hunt, 2015; Pie \& Meyer, 2017), we

96 might expect that pelagic organisms, because of their innately greater dispersal ability (at least as

97 adults), might show different patterns relative to taxa that were benthic (Rojas et al., 2017;

98 Yacobucci, 2017). This greater dispersal ability might allow pelagic organisms to more fully

99 occupy potentially available habitats than benthic organisms, which could lead to larger

100 geographic ranges and also less change in geographic ranges through time. (In addition, there

101 are certain paleoecological constraints that reduce the dispersal potential of cephalopods, such as

102 minimum water depth required for vertical migration, Ward and Westermann, 1985; Ritterbush

103 et al., 2014; R. T. Becker, 2019, pers. comm.) It also could potentially influence patterns of

104 speciation and extinction by dampening opportunities for geographic isolation and creating

105 larger effective population sizes. Further, sea-level fall is known to cause regular and repeated

106 patterns of extinction in ammonoids (Kullmann, 1983, 1985; House, 1985; Hallam, 1987; Becker

107 \& Kullmann, 1996; Wiedmann \& Kullmann, 1996; Kaiser et al., 2011; Zhang et al., 2019; and R.

108 T. Becker, 2019, pers. comm.).

109

110 This study focuses on cephalopods from the Pennsylvanian-early Permian (Morrowan, Atokan,

111 Desmoinesian, Missourian, Virgilian, and Wolfcampian) in the Midcontinent Sea of the United

112 States as knowledge of their systematic affinities, geographic distribution and overall diversity is

113 relatively well understood (Miller, Dunbar, \& Condra,1933; Newell, 1936; Plummer \& Scott, 
114 1937; Miller \& Youngquist, 1949; Nassichuk, 1975; Boardman et al., 1994; Landman, Tanabe,

115 \& Davis, 1996; Kröger, 2005; Klug et al., 2015; Korn, Klug, \& Walton, 2015), the stratigraphy

116 of the region is well constrained (Heckel, 2008, 2013), and there are extensive exposures of

117 fossiliferous units in the region. Moreover, at this time the Midcontinent Sea was bordered by

118 the Antler Orogeny to the north, the Ancestral Rocky Mountain Orogeny to the west/northwest

119 and the Ouachita Mountain belt to the south/southeast (as well as various structural arches), such

120 that it constituted a distinct biogeographic region for marine invertebrates (Wells et al., 2007;

121 Nelson \& Lucas, 2011; Joachimski \& Lambert, 2015).

122

123 The Late Paleozoic Ice Age (LPIA) was the longest lived glacial period of the Phanerozoic and is

124 relatively well understood due to numerous stratigraphic, sedimentologic, paleontologic, and

125 isotopic studies (e.g., Mii, Grossman, \& Yancey,1999; Isbell, 2003; Stanley \& Powell, 2003;

126 Raymond \& Metz, 2004; Montañez, 2007; Powell, 2007; Tabor \& Poulsen, 2007; Fielding,

127 Frank, \& Isbell, 2008; Heckel, 2008; DiMichele et al., 2009; Bonelli \& Patzkowsky, 2011;

128 Montañez \& Poulsen, 2013; Balseiro, 2016; Roark et al., 2017; Segessenman \& Kammer, 2018).

129 Glacial cycling in the North American midcontinent region has received much study (e.g., Isbell,

130 2003; Heckel, 2008, 2013). Modern synthesis of the glacial history indicates that the Morrowan

131 to early Desmoinesian represented a localized glacial period, the late Desmoinesian to early

132 Virgilian represented a widespread interglacial period with minor glaciation, and the late

133 Virgilian to early Wolfcampian represented the apex of widespread glaciation (Montañez \&

134 Poulsen, 2013). Modeling predicts that sea-level oscillations in the late Pennsylvanian were

135 between 50-100 meters depending upon the number and volume of melting ice sheets, and that

136 water temperatures are estimated to have been between $4-7^{\circ} \mathrm{C}$ cooler during glacial maxima than 
137 inter-glacial periods (Heckel, 1986; Isbell, 2003; Montañez, 2007; Tabor, 2007; Heckel, 2008;

138 Cecil, DiMichele, \& Elrick, 2014). The sea-level and temperature changes were likely to have

139 had an important influence on species distribution and geographic range size during this time

140 (Waterhouse \& Shi, 2010). Perhaps cephalopod taxa would be less influenced by glacial sea-

141 level cycles than benthic taxa, as these cycles are also known to cause variation in seafloor

142 ventilation, with concomitant dysoxia/anoxia that is more severe for benthic taxa (A. Dunhill,

143 pers. comm., 2018). By contrast, sea-level fall is known to have caused ammonoid extinctions

144 and Paleozoic cephalopods were sensitive to water temperature (R. T. Becker, pers. comm., 145 2019).

\section{Materials and methods}

147

148

150

151

152

153

154

155

\section{Taxa considered, stratigraphic correlation, specimens examined, and georeferencing: 79}

species belonging to 26 genera (13 nautiloids and 13 ammonoids) of cephalopods in the Pennsylvanian-Permian North American Midcontinent Sea were considered (Table S1). These represent abundant, well preserved, and taxonomically well understood species for which we were able to obtain type material and collections material of sufficient quality to enable taxonomic assignments on a breadth of material. Other species from the mid-continent of North America certainly exist and adding these to our analyses could change our results. However, at this time it was not possible to consider these via obtaining type and other material for them and pursuing the significant additional taxonomic work this would entail. Therefore, results are based on consideration of what is essentially a random selection of some of the (albeit well known) species in the region and this analysis is best viewed as an initial approach to considering paleobiogeographic dynamics in the region. Range reconstructions relied on the occurrence 
161 records of specimens derived from a comprehensive consideration of the entire taxonomic

162 literature on the taxa studied. In particular, the following publications were utilized: Cox (1857),

163 Swallow (1858), McChesney (1860), Meek \& Worthen (1860, 1870), White \& St. John (1867),

164 White (1889), Hyatt (1891, 1893), Keyes (1894), Miller (1892), Smith (1896, 1903), Girty

165 (1911, 1915), Mather (1915) Böse (1919, 1920), Miller (1930), Sayre (1930), Miller, Dunbar, \&

166 Condra (1933), Miller \& Cline (1934), Miller \& Owen (1934, 1937, 1939), Foerste (1936),

167 Miller \& Thomas (1936), Newell (1936), Plummer \& Scott (1937), Elias (1938a, b), Miller \&

168 Moore (1938), Smith (1938), Miller \& Furnish (1940a, b, 1957), Teichert (1940), Clifton (1942),

169 Miller \& Unklesbay (1942), Young (1942), Sturgeon (1946), Miller, Lane, \& Unklesbay (1947),

170 Miller \& Downs (1948, 1950), Miller \& Youngquist (1947, 1949), Miller, Youngquist, \&

171 Nielsen (1952), Kummel (1953, 1963), Ruzhentsev \& Shimanskiy (1954), Unklesbay (1954),

172 Arkell et al. (1957), Unklesbay \& Palmer (1958), Hoare (1961), Furnish, Glenister, \& Hansman

173 (1962), McCaleb (1963), Gordon (1964), Miller \& Breed (1964), Teichert et al. (1964), Furnish

174 \& Glennister (1971), Ruzhentsev \& Bogoslovskaya (1971), Nassichuk (1975), Sturgeon et al.

175 (1982), Hewitt et al. (1989), Boardman et al. (1994), Kues (1995), White \& Skorina (1999),

176 Kröger \& Mapes (2005), Furnish et al. (2009), and Niko \& Mapes (2009) as well as from

177 examination of all specimens, including types, housed in: the Division of Invertebrate

178 Paleontology, Biodiversity Institute, University of Kansas (KUMIP); the University of Iowa

179 Paleontology Repository (UI); and the Yale University Peabody Museum of Natural History

180 (YPM). These institutions are among the most complete repositories of cephalopod diversity

181 from this region and time and contain many of the type specimens of the species examined.

182 Moreover, all specimens used in the analysis were personally examined and taxonomically-

183 vetted via consideration of the literature, relevant type specimens, and other material, with 
184 species assignments and determinations made by the first author. Over 1,100 specimens were

185 identified to species level in this study (Kolis, 2017). We chose to focus on the particular species

186 considered, rather than downloading data from the Paleobiology Data Base (PBDB), as we

187 wanted to be able to personally validate the taxonomic identity of specimens using collections

188 data in conjunction with the literature in order to present more rigorously corroborated

189 hypotheses about the geographic distributions of species. We consider this approach to be

190 complementary to those approaches that utilize the PBDB in paleobiogeographic studies. On the

191 one hand, our approach did limit the number of species we were able to consider. On the other

192 hand, we believe it is quite important to evaluate hypotheses about systematic affinities of fossil

193 specimens, the actual data of the fossil record themselves, in detail and thereby accurately define

194 the taxonomic units considered. Given that species represent key macroevolutionary units in

195 nature (Eldredge, 1989; Wiley \& Lieberman, 2011; Hendricks et al., 2014), correctly

196 characterizing them taxonomically, and thus validating the scope of their geographic

197 distributions, is critical. Moreover, it has recently been shown by Marshall et al. (2018) that

198 incorporating museum specimen data in the manner that our study has can greatly expand,

199 enhance, and improve knowledge of geographic distributions of fossil species, relative to studies

200 that only utilize data from the PBDB. In the case of some species, $\sim 30 \%$ of the total considered,

201 our analyses indicated moderate changes in stratigraphic range (addition of a stage, etc.) relative

202 to what is presented in the PBDB. This happened primarily because via this study we were able

203 to identify specimens to species that previously had been treated as indeterminate at the species

204 level, or we were able to determine that specimens had previously been mis-identified to species. 
206 Specimens were assigned to the Virgilian, Missourian, Desmoinesian, Atokan, Morrowan, or

207 Wolfcampian stages using the USGS National Geologic Map Database (U.S. Geological Survey, 208 2017), Sawin et al. (2006, 2008, 2009), Zeller (1968), Pope (2012), and Heckel (2013). The

209 temporal boundaries of stages were derived from Davydov, Korn, \& Schmitz (2012) (Table S2).

210 It is important to note that the boundaries of international stages are based on few

211 geochronological tie points and the correlation of the North American stage boundaries with

212 these is arbitrary; also, some of the boundaries used are still being researched (R. T. Becker,

213 pers. comm., 2019.) In addition, while more resolved stratigraphic assignment to biostratigraphic

214 zone is possible for units in Europe (e.g., Davydov \& Leven, 2003), the northern Appalachian

215 Basin of North America (e.g., Heckel et al., 2011), and parts of the North American

216 midcontinent (e.g., Boardman et al., 1994; Heckel et al., 2011), it is less tractable to associate the

217 boundaries of the biostratigraphic zones from the North American midcontinent with radiometric

218 dates for the stratigraphic units and regions considered herein. Furthermore, the museum

219 specimens considered herein lacked the information needed to make it possible to constrain them

220 to biostratigraphic zone, only stage. For this reason, it was unfortunately not possible to consider

221 changes in geographic range, nor rates of speciation and extinction, at a temporal scale more

222 resolved than stage. Although this is often the standard degree of temporal resolution used in a

223 variety of paleobiogeographic studies, it does entail that we were not able to discern events

224 transpiring more rapidly than the time scale of stage. This means that we will be missing

225 important patterns; although speciation and extinction does not appear to frequently be

226 transpiring within stage boundaries in this region, at least sometimes it is, and moreover

227 geographic range shifts by species were certainly happening within these boundaries. 
229 All specimen localities were georeferenced during the course of the study. GEOLocate (Rios \&

230 Bart, 2018) and the MaNIS Georeferencing Calculator (Wieczorek, 2015) were used to obtain

231 coordinates and uncertainty radii. All points were calculated in decimal degrees within the

232 WGS84 model in the GEOLocate (Rios \& Bart, 2018) world topo layer to ensure consistency

233 and accuracy in determinations. Most uncertainty radii were less than $10 \mathrm{kms}$. Any specimens

234 with questionable locality information were excluded from analyses, as were specimens with an

235 uncertainty radius larger than the county they were contained within. This left 950 specimens

236 (Table S1) to use in range reconstruction and statistical analysis of geographic range through

237 geologic time. All statistical analyses were performed using Minitab ${ }^{\circledR}$ Statistical Software

238 Minitab v. 17 (Minitab, 2016) and R-Studio Version 3.4.0 (2017).

239

240

241 (2004, 2005), Stigall \& Lieberman (2006), Hendricks, Lieberman, \& Stigall (2008), Myers \&

242 Lieberman (2011), Myers, MacKenzie, and Lieberman (2013), and Dunhill \& Wills (2015). In

243 particular, after specimen occurrence data were georeferenced and assigned to temporal bins,

244 Excel CSV files were compiled for the occurrence points for all specimens within species. CSV

245 files were imported into ArcGIS v. 10.3 (ESRI, 2014) and layers were created using geographic

246 coordinate system 'WGS 1984' and projected coordinate system 'WGS 1984 World Mercator'

247 (Fig. 1). These layers were input into PaleoWeb (The Rothwell Group LP, 2016) to rotate

248 coordinates into continental configuration and geographic position of the midcontinent region

249 during the Pennsylvanian-early Permian (Fig. 2). These paleo-coordinate layers were then re-

250 projected into ArcMap (ESRI, 2014).

251 Geographic range values were calculated for each species (Table S3) using minimum bounding

252 geometry. This method has been shown to provide the most accurate procedure for

Peer) reviewing PDF | (2018:09:31237:3:0:NEW 16 Mar 2019) 
253 reconstructing changes in geographic range, especially for fossil taxa (Darroch \& Saupe, 2018).

254 Convex hulls or buffers were given to every specimen occurrence point in each species and these 255 shapefiles were re-projected in 'South America-Albers Equal Area Conic'. This model was used

256 to accommodate the rotation of species occurrence coordinates into the southern hemisphere

257 during the late Paleozoic. Species with three or more occurrence points were given a convex hull 258 that spanned the entire area between occurrences (see Rode \& Lieberman, 2004; Hendricks, 259 Lieberman, \& Stigall, 2008; Myers \& Lieberman, 2011; and Darroch \& Saupe, 2018). In this 260 way, multiple occurrence points were combined to recreate the geographic range of a single

261 species. Species with only one occurrence point were given a $10 \mathrm{~km}^{2}$ buffer; species with just two

262 occurrence points were given a $10 \mathrm{~km}^{2}$ wide buffer which was used, in conjunction with their

263 distance, to derive an area value (following Rode \& Lieberman, 2004, 2005; Hendricks,

264 Lieberman, \& Stigall, 2008; Myers \& Lieberman, 2011; and Myers, MacKenzie, and Lieberman,

265 2013). Species geographic range size data were tested for normality within each temporal stage 266 using the Anderson-Darling normality test (this is a commonly used test to assess normality, see

267 Sokal \& Rohlf, 1994).

Assessing fossil record bias: A common concern when studying the fossil record is that there might be biases that could lead to inaccurate or artifactual findings. This concern can be manifold, but the two most pertinent issues here involve incomplete sampling and/or issues of

272 stratigraphic bias. While it is important to be aware of the fact that the fossil record is

273 incomplete, it is worth recognizing that there is a large body of research that demonstrates that

274 many of the biogeographic patterns preserved in the fossil record, particularly in marine settings,

275 represent real biological phenomena, rather than taphonomic artifacts (Myers \& Lieberman, 
276 2011; Rook, Heim, \& Marcot, 2013; Dunhill \& Wills, 2015), although that does not mean that

277 such artifacts played no role in this study. Further, it is also prudent to realize that sampling bias

278 is a common issue in studies of extant biodiversity and species distribution, and much work

279 needs to be done in this area to alleviate the biases of the extant biota (Lieberman, 2002;

280 Carrasco, 2013).

281

282 The possibility that biases in the fossil record might lead to artifactual results was assessed in a 283

284

285

286

287

288

289

290

291

292

293

294

295

296

297

few different ways. First, the relationship between outcrop availability and the geographic range of Pennsylvanian and Permian cephalopods was determined (see Myers \& Lieberman, 2011). A percent coverage table of the range size of species overlaid against temporal outcrop availability was created using ArcGIS v. 10.3 (ESRI, 2014). A low percentage of overlap between range size and outcrop area would suggest species distributions are more likely to reflect 'real'

biogeographic patterns while a high percentage of overlap would suggest the presence or absence of outcrop was significantly influencing results (Myers \& Lieberman, 2011; Myers, MacKenzie, \& Lieberman, 2013; however, see also Dunhill, 2012 for an alternative viewpoint). The second test used was an "n-1” jackknifing analysis (see Myers \& Lieberman, 2011; Myers, MacKenzie, \& Lieberman, 2013). This procedure sub-sampled species range size within each temporal bin to test the resilience of data to outliers. Mean range size estimations were generated for each temporal bin; these were input into a one-way ANOVA to compare jackknife estimates with the initial geographic range size estimates (Myers \& Lieberman, 2011; Myers, MacKenzie, \& Lieberman, 2013). Finally, a Pearson rank correlation test was performed to test the association of occurrence points and geographic range size; a close correlation would indicate that reconstructed ranges were very much dependent on sampling and suggest that reconstructed biogeographic patterns might be an artifact of a biased fossil record (Myers, MacKenzie, \& 
300 Lieberman, 2013).

301

302 Speciation and extinction rate calculations: Speciation and extinction rates were calculated in

303 order to consider macroevolutionary dynamics in cephalopods from the Late Paleozoic

304 Midcontinent Sea. Macroevolutionary rates were calculated using the following equation,

305 presented in Foote (2000) and Rode \& Lieberman (2005):

306

307

$$
\mathrm{N}_{\mathrm{f}}=\mathrm{N}_{0} \mathrm{e}^{\mathrm{rt}}
$$

308

309

where $\mathrm{N}_{0}$ is the species richness at the beginning of a temporal bin, $\mathrm{N}_{\mathrm{f}}$ is the species richness at the end of a temporal bin, $\mathrm{t}$ is the duration of a temporal bin, and $\mathrm{r}$ is the total rate of diversity

311 change. The temporal bins used were North American stages (Table S2). Species richness values

$312\left(\mathrm{~N}_{\mathrm{f}}\right)$ were determined for each temporal bin and were parsed into 'carry-over' $\left(\mathrm{N}_{0}\right)$ and 'new'

313 species richness values to ensure the accuracy of speciation and extinction rate calculation. In

314 this way, it was possible to calculate the rate of diversity change between bins. For example, $r$

315 Atokan $=\left(\ln \mathrm{N}_{0 \text {-Desmoinesian }}-\ln \mathrm{N}_{0 \text {-Atokan }}\right) / \mathrm{t}_{\text {Atokan }}$. Speciation rate within each temporal bin was

316 calculated using the equation $\mathrm{S}_{\text {Atokan }}=\left(\ln \mathrm{N}_{\mathrm{f} \text {-Atokan }}-\ln \mathrm{N}_{0 \text {-Atokan }}\right) / \mathrm{t}_{\text {Atokan, }}$, and extinction rate within

317 each temporal bin was calculated using the equation $\mathrm{E}_{\text {Atokan }}=\mathrm{S}_{\text {Atokan }}-\mathrm{r}_{\text {Atokan }}$ for each temporal

318 stage (Foote, 2000; Rode \& Lieberman, 2005).

319

320

\section{Results}

321

322 Paleobiogeographic patterns: Geographic range data were analyzed separately across all

323 cephalopods and individually for both nautiloids and ammonoids. As mentioned above, species 
324 geographic range size data were tested for normality within each temporal stage using the

325 Anderson-Darling normality test (see Sokal \& Rohlf, 1994). Range size data within each

326 temporal stage were not normally distributed for any data combination $(\mathrm{P}<0.005)$. Instead,

327 distributions were left skewed across all temporal stages for every data grouping. Data were

328 subsequently log-transformed to normalize data, and statistical analyses were performed on both

329 original and transformed data.

330

331 In general, geographic range size (either mean of transformed data or median of original) of

332 ammonoids and nautiloids increases during the Missourian and Virgilian stages (Fig. 3), which

333 was a time of sea-level rise due to warming during an interglacial (Isbell, 2003; Montañez \&

334 Poulsen, 2013), such that there may be an association between the sea-level rise and the increase

335 in geographic range. Another possibility is that there was some change in taphonomic or

336 collecting conditions associated with Virgilian strata that made it easier to discern the actual

337 biogeographic distributions of species at this time, relative to other time intervals (G. Piñeiro,

338 pers. comm., 2018). However, none of the changes in geographic range were statistically

339 significant, so it is not possible to infer strong correlation between the sea-level rise, or possible

340 taphonomic factors, and the range expansion. For instance, Mann-Whitney U tests, a non-

341 parametric test used to compare two sample medians (see Sokal \& Rohlf, 1994), found no

342 statistically significant changes (at $\mathrm{P} \leq 0.05)$ in median geographic range size for any temporal

343 stages separately across all studied cephalopods, as well as individually for nautiloids and

344 ammonoids, even prior to correction for multiple comparisons. This is because for the

345 cephalopods studied median range values are constant through time $\left(79 \mathrm{~km}^{2}\right)$. Mean values

346 (which are also relevant for understanding patterns of change in the data, G. Piñeiro, pers. 
347 comm., 2019) do show more change through time in our data than the corresponding median

348 values, as might be expected, but median values are better to focus on for statistical purposes

349 when the data are not normally distributed, as is the case herein.

350

351 The same was true for two-sample t-tests (see Sokal \& Rohlf, 1994) performed on log-

352 transformed data which again found no statistically significant changes $($ at $\mathrm{P} \leq 0.05)$ in mean

353 geographic range size though time, even prior to employing a statistical correction needed in the

354 case when there are multiple comparisons. Again, recall that mean range size data are shown in

355 Figure 3, and the differences among log-transformed data through time are far less substantial

356 (and ultimately not significant). Furthermore, a one-way ANOVA, either with or without the

357 assumption of equal variance, failed to find any significant differences (at $\mathrm{P} \leq 0.05)$ between

358 stages for log-transformed mean geographic range size across all cephalopods as well as

359 individually for nautiloids and ammonoids. Still, it is worth noting that changes in range size are

360 occurring through time, most notably in the Virgilian, and these could be related to climatic

361 changes that occurred then, and also changes in the paleogeography of the region, although in the

362 absence of statistical evidence we could not convincingly document such a link in the present

363 study. However, it is important to note that previous studies (e.g., Ramsbottom, 1981) have

364 documented such a link.

365

366 Analysis of macroevolutionary rates: Speciation rate (S) and extinction rate (E) were

367 calculated for the Atokan, Desmoinesian, Missourian, and Virgilian stages across all selected

368 cephalopods and within selected nautiloids and ammonoids, respectively. The S and E presented

369 across all selected cephalopods are comprised of two calculations; one calculation included taxa 
370 that only occurred in a single temporal stage (singletons) (Table 1; Fig. 4), while the other

371 calculation excluded taxa that occurred in a single temporal stage (Table S4). S and E were also

372 calculated for ammonoids and for nautiloids including (Tables S5, S6) and excluding taxa that

373 occurred in a single stage (Tables S7, S8). Note, due to the dependence of calculations on

374 diversity metrics from both adjacent stages, it is not possible to accurately calculate the rate of

375 biodiversity change (R), or S and $\mathrm{E}$ for the first stage considered, the Morrowan, nor $\mathrm{R}$ or $\mathrm{E}$ for

376 the last stage considered, the Wolfcampian (these are thus left blank in Table 1 and Tables S4-

377 S8). While it might have been possible to infer S and E using other methods, to do so would

378 exaggerate the significance of edge effects and thus be problematic (Foote, 2000). A problem

379 with including singleton taxa is that since they speciate and go extinct in the same interval there

380 will always be a direct one to one correlation between S and E (Vrba, 1987; Foote, 2000). This

381 is why for studies considering the relationship between $\mathrm{S}$ and $\mathrm{E}$ it is recommended that

382 singletons be excluded (Vrba, 1987; Foote, 2000). However, when singletons are not included, a

383 higher proportion of ammonoids cannot be considered, as many of these have short

384 biostratigraphic ranges (R. T. Becker, pers. comm., 2019). To address each of these concerns we

385 have presented calculations both with and without singletons.

386

387 Across all cephalopods studied, S was high in the Atokan and Desmoinesian, fell in the

388 Missourian, and reached very low levels in the Virgilian and Wolfcampian (Fig. 4). By contrast,

389 E was low in the Atokan and Desmoinesian, began to rise in the Missourian, and reached even

390 higher levels in the Virgilian (Fig. 4). Essentially, across all cephalopods examined, when S is

391 high, $\mathrm{E}$ is low, and when $\mathrm{S}$ is low, $\mathrm{E}$ is high. This is potentially contrary to the pattern expected

392 with an ecological opportunity model of speciation (Simões et al., 2016), although the specific 
393 processes driving the diversification could not be determined at this time. However, it is

394 possible that when S was high there may have been many short-lived species that could not be

395 sampled that were actually going extinct, and this phenomenon would artificially depress E. To

396 consider this in more detail, what is truly needed is a zone by zone analysis of all cephalopod

397 species known from the North American midcontinent (R. T. Becker, 2019, pers. comm.).

399 As expected, S and E are lower when singletons are excluded (see Tables 1, S4). Segesseman \&

400 Kammer (2018) found in their macroevolutionary study on crinoids from this interval that

401 including or excluding singletons substantially influenced their results, but in our study including

402 or excluding these did not produce a substantial change. Notably, S and E patterns diverge

403 somewhat between ammonoids and nautiloids when considered individually (and the patterns in

404 nautiloids better match the overall patterns across all the cephalopods studied). For instance, in

405 nautiloids $\mathrm{S}$ is high in the Atokan and Desmoinesian, then declines to moderate in the

406 Missourian, and is at its lowest in the Missourian and Wolfcampian (Table S6), whereas in

407 ammonoids S is only high in the Atokan, declines to moderate in the Desmoinesian, declines

408 somewhat more in the Missourian and then remains essentially constant through the

409 Wolfcampian (Table S5). In addition, E is low in ammonoids during the Desmoinesian and

410 Missourian but high in the Atokan and Wolfcampian (Table S5), whereas in nautiloids there are

411 no observed extinctions during the Atokan; values remain quite low for nautiloids in the

412 Desmoinesian, rise somewhat in the Missourian, and then rise again in the Virgilian (Table S6).

413

414 An important caveat regarding the calculation of $\mathrm{S}$ is that many of the species analyzed belong to

415 genera that were widely distributed beyond the Midcontinent Sea during the Late Paleozoic. 
416 Thus, although none of the species considered in these analyses occurred outside of the

417 Midcontinent Sea, their close relatives did. It is conceivable that while speciation events and

418 rates by necessity are herein treated as occurring in situ, this might not always have been the

419 case. Instead, some speciation events could have occurred outside of the Midcontinent Sea with

420 subsequent invasion events into that region. These invasions would appear as in situ speciation

421 events in this analysis, although they actually were not. In the absence of phylogenetic

422 hypotheses for the genera considered it is not currently possible to consider how much of the

423 pattern pertaining to speciation rate shown in Fig. 4 is due to invasion instead of speciation such

424 that both might be playing a role (Metacoceras is one example where the genus occurs well

425 outside of the North American mid-continent, it is known to occur in beds $\sim 100 \mathrm{kms}$ southeast of

426 Moscow, Russia, such that some of the cladogenetic events involving this genus might comprise

427 instances of invasion). Further, a related phenomenon could affect the calculation of E: at times

428 what were treated as extinction events might have simply been local extinctions in the

429 Midcontinent Sea which could have included emigration to other regions. As mentioned

430 previously, it does not appear that any of the species considered occur outside of the

431 Midcontinent Sea, but a phylogenetic hypothesis for these groups would be valuable for

432 considering this issue in greater detail.

433

434 Relationship between biogeography and macroevolutionary rates: Across all the

435 cephalopods studied, mean geographic range size increased during the Virgilian (and in

436 ammonoids first in the Missourian but then more prominently in the Virgilian) and declined in

437 the Wolfcampian (Fig. 3); speciation rates were generally high in the Atokan and Desmoinesian

438 and fell in the Virgilian (Fig. 4); extinction rates were generally low in the Atokan and 
439 Desmoinesian and rose in the Virgilian (Fig. 4). The Pearson correlation test in Minitab 17

440 (Minitab, 2016) was used to examine the association between geographic range and either

441 speciation rate extinction rate in greater detail. No significant (at $\mathrm{P} \leq 0.05$ ) correlation between

442 speciation or extinction rate and range size was found across all cephalopods or within

443 ammonoids or nautiloids individually (Table 2). However, in cases the values approach $\mathrm{P}=0.05$.

444 For instance, the association between

445 decreasing geographic range size and increasing extinction for all cephalopods and for

446 ammonoids alone, so it is clear that generally there is some association between the two, but

447 unfortunately significant support at the .05 level is lacking. We note that numerous previous

448 studies have documented an association between decreasing geographic range size and

449 increasing extinction rate (e.g. Vrba, 1980; Jablonski, 1986; Eldredge, 1989; Stanley, 1990;

450 Jablonski \& Roy, 2003; Rode \& Lieberman, 2004, 2005; Kiessling \& Aberhan, 2007; Payne \&

451 Finnegan, 2007; Stigall, 2010; Dunhill \& Wills, 2015; Jablonski \& Hunt, 2015; Orzechowski et

452 al., 2015; Saupe et al., 2015; Castiglione et al., 2017; Pie \& Meyer, 2017; Lam, Stigall, \&

453 Matzke, 2018; Schneider, 2018) and thus this a very robust phenomenon in general and likely to

454 be operating to some extent herein. However, over this time interval and for this particular group

455 of species the association is not statistically significant (Table 2), probably because sample sizes

456 are not large, and further this is likely because many taxa were culled by the late Mississippian

457 extinction (M. Powell, pers. comm., 2018). Further, sample size could also be influencing the

458 results pertaining to changes in geographic range size through time (G. Piñeiro, pers. comm.,

459 2019).

460 
461 Analysis of fossil record bias: The low percentage of overlap between cephalopod species

462 geographic ranges and the availability of outcrop, less than $1 \%$ in 29 out of 30 species (Table S9;

463 the one species with a larger percentage value, "Orthoceras" kansasense, occurs throughout the

464 Midcontinent Sea), suggests the results are not simply an artifact of an incomplete fossil record,

465 at least pertaining to outcrop availability or changes in the paleogeography of the region. The

466 "n-1" jackknifing analysis also supports the robustness of the reconstructed ranges, as no

467 statistically significant differences were found between the mean of the reconstructed and

468 subsampled range values for any time interval (all P-values $>0.9$ ), suggesting that one or a few

469 occurrence records are not having a major influence on biogeographic patterns. Similar results

470 were found in other taxa and time periods by Hunt, Roy, \& Jablonski (2005), Myers \&

471 Lieberman (2011), and Myers, MacKenzie, \& Lieberman (2013), although Dunhill, Hannisdal,

$472 \&$ Benton (2014) did find some association between outcrop area and diversity in the case of the

473 marine fossil record of Great Britain. Finally, the Pearson correlation test shows no correlation (-

$4740.055, \mathrm{P}-$ Value $=0.789)$ between the number of occurrence points and geographic range size;

475 this provides further evidence that the biogeographic signatures of Late Paleozoic cephalopods

476 are unlikely to be simply an artifact of the fossil record.

477

478 Diversity patterns: Across all cephalopods, species richness increased from the Morrowan to 479 the Atokan, peaked in the Desmoinesian, and decreased through the Wolfcampian (Fig. S1). A 480 similar pattern is seen in the nautiloids (Fig. S2). However, the ammonoids (Fig. S3) demonstrate 481 an earlier peak in the Atokan, followed by a Desmoinesian to Virgilian plateau, with a decrease 482 in the Wolfcampian. This indicates that the data from nautiloids are most influencing the 483 recovered patterns (G. Piñeiro, pers. comm., 2019). Notably, previous studies of late Paleozoic 
484 brachiopod communities in Bolivia showed a consistent trend between diversity and glacial

485 cycling with increased diversity during glacial periods and decreased diversity during inter-

486 glacial periods (Badyrka, Clapham, \& Lopez, 2013). However, there seems to be less

487 consistency between species richness trends and glacial cycling in the Midcontinent Sea. For

488 instance, there is an increase in cephalopod species richness throughout the Morrowan to

489 Desmoinesian associated with localized glaciation, and an interglacial period with generally

490 minor glaciation is associated with a decrease in cephalopod species richness from the

491 Desmoinesian to Virgilian, yet by contrast widespread glaciation is associated with a decrease in

492 species richness from the Virgilian to the Wolfcampian. Important points, however, are that these

493 are raw diversity patterns, and sample standardized diversity patterns show a different result (M.

494 Powell, pers. comm., 2018), and further that brachiopods and cephalopods can show different

495 behaviors in response to climatic changes (G. Piñeiro, pers. comm., 2019).

\section{Discussion}

497

498

499

Geographic range shifts through time are one of the pervasive phenomena in the history of

500 life; these are manifest both within species and higher-level clades, occur at a number of

501 different time scales, and are frequently linked to climatic change (Wiley \& Lieberman, 2011).

502 Specific examples do come from the late Paleozoic, a time of extensive climate change including

503 profound glaciation along with numerous glacial and interglacial cycles and associated cycles of

504 sea-level rise and fall (Montañez and Poulsen, 2013). (Previous studies of ammonoids have

505 shown that these changes in sea-level may have caused more significant changes in

506 biogeographic ranges of taxa than temperature changes during this time period, and other time

507 periods as well [Hallam, 1987; Hartenfels \& Becker, 2016; Zhang et al., 2019]). Those changes 
508 impacted patterns of geographic range in both terrestrial plant (e.g., DiMichele et al., 2009;

509 Falcon-Lang \& DiMichele, 2010) and marine invertebrate ecosystems (e.g., Ramsbottom, 1981;

510 Leighton, 2005; Powell, 2007; Waterhouse \& Shi, 2010; Balseiro \& Halpern, 2019). When it

511 comes to marine invertebrates from this time interval, most of the focus has been on the highly

512 diverse benthic faunas (e.g., Stanely \& Powell, 2003; Powell, 2007; Bonelli \& Patzkowsky,

513 2011; Balseiro, 2016; Segessenman \& Kammer, 2018; Balseiro \& Halpern, 2019); however, taxa

514 that have a pelagic life style are also worth examining. Herein, 79 pelagic species of

515 cephalopods were examined for patterns of range size change using GIS and although in general

516 these species exhibit some evidence for changes in geographic range size (Fig. 3) especially in

517 the Virgilian, and to a lesser extent in the Missourian, those changes were not statistically

518 significant, making it hard to directly tie them to climate changes. However, there is strong

519 evidence that climate change played a prominent role in influencing geographic range of

520 cephalopods from other regions during this time period (e.g., Ramsbottom, 1981) and indeed in

521 cephalopods from other time periods (e.g., Hallam, 1987; Jacobs et al., 1994; Kaiser et al., 2011;

522 Hartenfels \& Becker, 2016; Zhang et al., 2019). In a similar vein, many paleontological studies

523 have demonstrated that species with larger geographic ranges tend to have lower extinction rates

524 than species with narrower geographic range sizes (e.g., Vrba, 1980; Jablonski, 1986; Eldredge,

525 1989; Stanley, 1990; Rode \& Lieberman, 2004; Stigall \& Lieberman, 2006; Payne \& Finnegan,

526 2007; Stigall, 2010; Hopkins, 2011; Dunhill \& Wills, 2015). Again, this phenomenon is not

527 found to be statistically significant in the case of the late Paleozoic cephalopod species

528 considered herein (Table 2), but there is some general quantitative evidence for the phenomenon. 
530 There may be a few different explanations for these findings. First, it may be that some

531 cephalopod species were not significantly affected by the glacial-interglacial climatic cycles

532 transpiring within the Late Paleozoic Midcontinent Sea. A second possible explanation, perhaps

533 coupled to the first, is that since cephalopods are highly mobile relative to benthic marine

534 invertebrates such as gastropods, bivalves, brachiopods, etc., they can more easily occupy a

535 greater portion of their potential range. Further, perhaps the available potential range of

536 cephalopod species does not change much in glacial relative to interglacial regimes. This may

537 seem unlikely given the vast fluctuations in sea level occurring at the time, but pelagic marine

538 organisms, because of their ease of dispersal, may more easily maintain consistent geographic

539 ranges relative to benthic counterparts. Another possible explanation for the pattern retrieved is

540 that, given the limits of stratigraphic correlation, sample size, and the completeness of the fossil

541 record, it was necessary for the analyses of species distribution conducted herein to focus on the

542 time scale of geological stages, whereas in actuality there were climatic changes occurring within

543 stages (Heckel, 2008, 2013); these certainly did cause fluctuations in species' geographic ranges

544 within stages, but simply could not be observed in the present study. The inability to observe

545 changes in geographic range size of species at a scale more resolved than stage, in particular,

546 likely played an important limiting role in the conclusions that could be derived. For instance,

547 other studies such as Ramsbottom (1981) have looked at European taxa from the same time

548 period, but focused at the level of zones, and did find a strong association between climate, sea-

549 level, and geographic distribution. A final set of explanations are related to the issue of sampling.

550 For instance, it was more difficult for the analyses presented herein to detect a relationship

551 between geographic range size and macroevolutionary rate because speciation and extinction

552 rates could only be calculated for four stages. Although we did not observe a substantial amount 
553 of speciation and extinction occurring within stage boundaries, certainly being able to consider

554 more stages would have enhanced our ability to retrieve patterns. We suspect that another

555 important explanation for our results is the relatively limited number of species that could be

556 considered herein. An expansion in the number of taxa considered could absolutely change our

557 results in various ways, including via increasing statistical power. Thus, what is presented herein

558 should only be treated as preliminary results that require further data and additional testing. We

559 would note, though, that detailed taxonomic vetting of specimens, including through comparison

560 of type material, especially involving taxonomic studies conducted in some cases more than 70

561 years ago, requires a significant amount of time investment. Thus, dramatic expansions to this

562 dataset would require concomitant investments of time. However, other datasets such as

563 AMMON and the PBDB could be used if one did not feel it was necessary to spend time vetting

564 taxonomic assignments. Although we posit that it is important to vet taxonomic assignments that

565 may be outdated, we would assert that our approach should be viewed as complementary to

566 approaches that rely on mining currently existing paleontologically oriented databases, and that

567 both types of approaches have value. As a final possible explanation for our results, we further

568 note that a common concern when studying the fossil record is the potential role biases can play.

569 This concern can be manifold. It is somewhat obviated by the results presented herein regarding

570 the apparent quality of the fossil record, but that does not mean that there are no inherent

571 problems with the cephalopod record that are at present difficult to ascertain; these could be

572 influencing the results retrieved in some at present unspecified way.

573

574 There is, however, another finding contrary to what might typically be expected for the late

575 Paleozoic that is worth mentioning. That is the fact that there seems to have been at least some 
576 moderate degree of evolutionary diversification and turnover within cephalopods, such that

577 species diversity did fluctuate throughout the Pennsylvanian and early Permian. Pennsylvanian

578 rates of macroevolution are typically classified as 'sluggish' or 'stolid' across all marine animals,

579 and Sepkoski (1998) formalized the notion that there was a marked decline in evolutionary rates

580 of Carboniferous and Permian marine faunas. Stanley \& Powell (2003) reiterated this result and

581 identified low mean macroevolutionary rates for marine invertebrate taxa. Bonelli \&

582 Patzkowsky (2011) also documented a pattern of low turnover in the face of major episodes of

583 sea-level rise and fall due to climatic change. The results from the analyses presented herein

584 could indicate that macroevolutionary rate in the case of late Paleozoic cephalopods was more

585 dynamic than often thought, supporting the conclusions of a variety of other important studies

586 considering late Paleozoic ammonoid diversity including Kullmann (1983, 1985), House (1985),

587 Becker \& Kullman (1996), Wiedmann \& Kullmann (1996), and Kullmann, Wagner, \& Winkler

588 Prins (2007). One possible reason why cephalopods may show a higher rate of diversification

589 than other groups is that they were a fairly evolutionarily volatile group (Lieberman \& Melott,

590 2013); thus, relative to many other marine invertebrate groups, they had relatively high rates of

591 speciation and extinction (Stanley, 1979; Jacobs et al., 1994; Landman, Tanabe, \& Davis, 1996;

592 Monnet, De Baets, \& Klug, 2011; Klug et al., 2015; Korn, Klug, \& Walton, 2015). However, this

593 may not be the entire explanation, as some other groups also show elevated rates of speciation

594 and extinction during this time interval. For instance, Balseiro (2016) and Balseiro and Halpern

595 (2019) did document evolutionary turnover at high latitudes, and elevated evolutionary rates

596 have also been found in fusulinid foraminifera (Groves \& Lee, 2008; Groves \& Yue, 2009) and

597 advanced cladid crinoids (Segessenman \& Kammer, 2018). Ultimately, we support the

598 contention raised by Segessenman \& Kammer (2018) that patterns from a few individual groups 
599 do not refute the general pattern of sluggish macroevolution postulated for this time period in the

600 history of life. The results may lend credence to the notion that macroevolutionary patterns

601 across all marine animals are rarely unitary for any one time period in the history of life, and

602 instead often tend to be variegated.

603

604 Conclusions

605

606 Patterns of range size change in late Paleozoic cephalopods from the North American

607 Midcontinent Sea were investigated using GIS. These species do exhibit some evidence for

608 changes in geographic range size through time, but the changes were not statistically significant

609 nor could they be directly tied to climate change. Further, in contradistinction to what is usually

610 found in the fossil record, cephalopod species with larger geographic ranges were not found to

611 have lower extinction rates than species with narrower geographic ranges. These distinctive

612 patterns may perhaps be related to the fact that cephalopods are pelagic and highly mobile, at

613 least relative to many benthic marine invertebrates, but it may also be due to the fact that only 79

614 species could be considered in our study, or to the fact that we were constrained to analyze

615 patterns at the temporal level of stage. Finally, the group shows more evolutionary

616 diversification and turnover during the Pennsylvanian and early Permian than is typical of other

617 marine invertebrate groups and this could be related to the fact that cephalopods are an

618 evolutionarily volatile group.

619

620 Acknowledgements

621 
622 Thanks to Chris Beard, Kirsten Jensen, Julien Kimmig, and Luke Strotz for very helpful

623 discussions on this work and thanks to them and Matthew Powell, Alexander Dunhill, Ralph

624 Thomas Becker, Dieter Korn, Graciela Piñeiro, Thomas Algeo, and Wolfgang Kiessling for

625 comments on previous versions of the manuscript. Thanks to Julien Kimmig for assistance with

626 collections related matters and for providing access to specimens in the KUMIP; thanks to

627 Tiffany Adrain for assistance with collections related matters and for providing access to

628 specimens in the UI; and thanks to Susan Butts for assistance with collections related matters and

629 for providing access to specimens in the YPM. Thanks to Michelle Casey and Erin Saupe for

630 assistance with stratigraphic correlations and use of GIS.

631

632 References

633

634 Abe FR, Lieberman BS. 2009. The nature of evolutionary radiations: a case study involving

635 Devonian trilobites. Evolutionary Biology 36:225-234.

636 Arkell WJ, Furnish WM, Kummel B, Miller AK, Moore RC, Schindewolf OH, Sylvester-Brady

637

PC, Wright CW. 1957. Part L. Mollusca Cephalopoda Ammonoidea. Treatise on

638 Invertebrate Palaeontology. Lawrence, Kansas: Geological Society of America.

Badyrka K, Clapham ME, Lopez S. 2013. Paleoecology of brachiopod communities during the late Paleozoic ice age in Bolivia (Copacabana Formation, Pennsylvanian-Early Permian). Palaeogeography, Palaeoclimatology, Palaeoecology 387:56-65.

642 Balseiro D. 2016. Compositional turnover and ecological changes related to the waxing and waning of glaciers during the Late Paleozoic ice age in ice-proximal regions 
(Pennsylvanian, western Argentina). Paleobiology 42:335-357.

645 Balseiro D, Halpern K. 2019. Immigration and extirpation selectivity patterns of brachiopods

Becker RT, Kullmann J. 1996. Paleozoic amonoids in space and time. In: Landman NH, Tanabe K, Davis RA, eds. Ammonoid Paleobiology. Boston: Springer, 711-753.

Boardman DR II, Work DM, Mapes RH, Barrick JE. 1994. Biostratigraphy of middle and late Pennsylvanian (Desmoinesian-Virgilian) ammonoids. Kansas Geological Survey Bulletin

Bonelli JR, Patzkowsky ME. 2011. Taxonomic and ecologic persistence across the onset of the

Böse E. 1919. The Permo-Carbonioferous ammonoids of the Glass Mountains, West Texas, and their stratigraphical significance. University of Texas Bulletin 1762:1-241.

Böse E. 1920. On ammonoids from the Abo Sandstone of New Mexico and the age of the beds

661 which contain them. American Journal of Science 49:51-60.

Brooks DR, McLennan DA. 1991. Phylogeny, Ecology, and Behavior: a Research Program in 663 Comparative Biology. Chicago: University of Chicago Press.

664 Carrasco MA. 2013. The impact of taxonomic bias when comparing past and present species 
diversity. Palaeogeography, Palaeoclimatology, Palaeoecology 372:130-137.

666 Castiglione S, Mondanaro A, Melchionna M, Serio C, Di Febbraro M, Carotenuto F, Raia

P. 2017. Diversification rates and the evolution of species range size frequency

668 distribution. Frontiers in Ecology and Evolution 5:147, 1-10.

Cecil CB, DiMichele WA, Elrick SD. 2014. Middle and Late Pennsylvanian cyclothems, American Midcontinent: Ice-Age environmental changes and terrestrial biotic dynamics. Comptes Rendus Geoscience 346:159-168.

Clifton RL. 1942. Invertebrate faunas from the Blaine and the Dog Creek formations of the Permian Leonard Series. Journal of Paleontology 16:685-699.

Cox DD. 1857. First report of a geological reconnoissance of the northern countries of Arkansas, made during the years 1857 and 1858. Arkansas Geological Survey. data. Paleobiology 44:25-39.

Davydov VI, Leven EJ. 2003. Reconstructing geographic range-size dynamics from fossil data. Palaeobiogeography, Palaeoclimatomology, Palaeoecology 196:39-57.

Davydov VI, Korn D, Schmitz MD. 2012. Chapter 23 - The Carboniferous Period. In: Amsterdam: Elsevier, 603 - 651. shifts in the late Paleozoic ice age earth. Geobiology 7:200-226. 
686

687

rock outcrop and exposure area compared with coastal proximity, topography, land use, and lithology. Paleobiology 38:126-143.

Dunhill AM, Wills MA. 2015. Geographic range did not confer resilience to extinction in terrestrial vertebrates at the end-Triassic crisis. Nature Communications 6:7980.

Dunhill AM, Hannisdal B, Benton MJ. 2014. Disentangling rock record bias and commoncause from redundancy in the British fossil record. Nature Communications 5:4818.

Eldredge N. 1989. Macroevolutionary Dynamics: Species, Niches, and Adaptive Peaks. New York: McGraw-Hill.

Eldredge N, Gould SJ. 1972. Punctuated equilibria: an alternative to phyletic gradualism. In: Schopf TJM, ed. Models in Paleobiology. San Francisco: Freeman, Cooper, 82-115.

Elias MK. 1938a. Properrinites plummeri Elias, n. gen and sp., from late Paleozoic rocks of Kansas. Journal of Paleontology 12:101-105.

Elias MK. 1938b. Revision of Gonioloboceras from late Paleozoic rocks of the midcontinent region. Journal of Paleontology 12:91100.

ESRI. 2014. ArcGIS Desktop: Release 10.3. Redlands, CA: Environmental Systems Research Institute.

Falcon-Lang HJ, DiMichele WA. 2010. What happened to the coal forests during Pennsylvanian glacial phases? Palaios 25:611-617.

Fielding CR, Frank TD, Isbell JL. 2008. The Late Paleozoic Ice Age: a review of current understanding and synthesis of global climate patterns. Geological Society of America Special Paper 441:343-354. 
708 Foerste AF. 1936. Silurian cephalopods of the Port Daniel area on Gaspé Peninsula, in eastern Canada. Bulletin of Denison University, Journal of the Scientific Laboratories 31:21-92.

710 Foote M. 2000. Origination and extinction components of taxonomic diversity: general problems. Paleobiology 26:74-102.

712 Furnish WM, Glenister BF. 1971. Permian Gonioloboceratidae (Ammonoidea). Smithsonian Contributions to Paleobiology 3:301-312.

714 Furnish WM, Glenister BF, Hansman RH. 1962. Brachycycloceratidae, novum, deciduous Pennsylvanian nautiloids. Journal of Paleontology 36:1341-1356.

Furnish WM, Glenister BF, Kullmann J, Zhou Z. 2009. Part L. Mollusca 4, Revised, Vol. 2: Carboniferous and Permian Ammonoidea (Goniatitida and Prolecanitida), pg. 136-144. Treatise on Invertebrate Palaeontology. Lawrence: The University of Kansas Paleontological Institute.

Girty GH. 1911. On some new genera and species of Pennsylvanian fossils from the Wewoka Formation of Oklahoma. Annals of the New York Academy of Sciences 21:119-156.

Girty GH. 1915. Fauna of the Wewoka Formation of Oklahoma. United States Geological Survey Bulletin 544:1-353.

Gordon M. 1964. Carboniferous cephalopods of Arkansas. United States Geological Survey Professional Paper 460:1-322.

Groves JR, Lee A. 2008. Accelerated rates of foraminiferal origination and extinction during the late Paleozoic ice age. Journal of Foraminiferal Research 38:74-84. Paleobiology 35:367-392. 
730 Hallam A. 1987. Radiations and extinctions in relation to environmental change in the marine Lower Jurassic of northwest Europe. Paleobiology 13:152-168.

732

733

734

735

736

737

738

739

740

741

742

743

744

745

746

747

748

749

750

751

Hartenfels S, Becker RT. 2016. The global Annulata events: review and new data from the Rheris Basin (northern Tafilalt) of SE Morocco. Geological Society of London, Special Publications 423:291-354.

Heckel PH. 1986. Sea-level curve for Pennsylvanian eustatic marine transgressive-regressive depositional cycles along midcontinent outcrop belt, North America. Geology 14:330334.

Heckel PH. 2008. Pennsylvanian cyclothems in midcontinent North America as far-field effects of waxing and waning of Gondwana ice sheets. Geological Society of America Special Paper 441:275-289.

Heckel PH. 2013. Pennsylvanian cyclothems of northern midcontinent shelf and biostratigraphic correlation of cyclothems. Stratigraphy 10:3-40.

Heckel PH, Barrick JE, Rosscoe SJ. 2011. Condonot-based correlation of marine units in the lower Conemaugh Group (Late Pennsylvanian) in Northn Appalachian Basin. Stratigraphy 8:253-269.

Hendricks JR, Lieberman BS, Stigall AL. 2008. Using GIS to study palaeobiogeographic and macroevolutionary patterns in soft-bodied Cambrian arthropods. Palaeogeography, Palaeoclimatology, Palaeoecology 264:163-175.

Hendricks JR, Saupe EE, Myers CE, Hermsen EJ, Allmon WD. 2014. The generification of the fossil record. Paleobiology 40:511-528.

Hewitt RA, Dokainish MA, El Aghoury M, Westermann GE. 1989. Bathymetric limits of a 
753

754

Hoare RD. 1961. Desmoinesian Brachiopoda and Mollusca from southwest Missouri. Missouri University Studies 36:1-262.

Hopkins MJ. 2011. How species longevity, intraspecific morphological variation, and geographic range size are related: a comparison using Late Cambrian trilobites. Evolution 65:3253-3273.

House MR. 1985. Ammonoid extinction events. Philosophical Transactions of the Royal Society of London Series B 325:307-326.

Hunt G, Roy K, Jablonski D. 2005. Species-level heritability reaffirmed: a comment on 'on the heritability of geographic range sizes'. American Naturalist 166:129-135.

Hyatt A. 1891. Carboniferous cephalopods. Geological Survey of Texas Annual Report 2:329-356.

Hyatt A. 1893. Carboniferous cephalopods: Second paper. Geological Survey of Texas Annual Report 4:377-474.

Isbell JL. 2003. Timing of the late Paleozoic glaciation in Gondwana: was glaciation responsible for the development of northern hemisphere cyclothems? Geological Society of America Special Paper 370:5-24.

Jablonski D. 1986. Larval ecology and macroevolution in marine invertebrates. Bulletin of Marine Science 39:565-587.

Jablonski D, Hunt G. 2015. Larval ecology, geographic range, and species survivorship in Cretaceous mollusks: organismic versus species-level explanations. American Naturalist 168:556-564. 
773 Jablonski D, Roy K. 2003. Geographical range and speciation in fossil and living

774 molluscs. Proceedings of the Royal Society of London, Series B 270:401-406.

775 Jacobs DK, Landman NH, Chamberlain JA Jr. 1994. Ammonite shell shape covaries with

776 facies and hydrodynamics: iterative evolution as a response to changes in basinal

777 environment. Geology 22:905-908.

778 Joachimski MM, Lambert LL. 2015. Salinity contrast in the US Midcontinent Sea during

779 Pennsylvanian glacio-eustatic highstands: evidence from conodont apatite $\delta 18 \mathrm{O}$.

780 Palaeogeography, Palaeoclimatology, Palaeoecology 433:71-80.

781

782

783

784

785

786

787

788

789

790

791

792

793

Kaiser SI, Becker RT, Steuber T, Aboussalam SZ. 2011. Climate-controlled mass extinctions, facies and and sea-level changes around the Devonian-Carboniferous boundary in the eastern Ati-Atlas (SE Morocco). Palaeogeography, Palaeoclimatology, Palaeoecology 310:340-364.

Keyes CR. 1894. Paleontology of Missouri. Missouri Geological Survey 4:1-226.

Kiessling W, Aberhan M. 2007. Geographical distribution and extinction risk: lessons from Triassic-Jurassic marine benthic organisms. Journal of Biogeography 34:1473-1489.

Klug C, Korn D, De Baets K, Kruta I, Mapes RH, eds. 2015. Ammonoid Paleobiology: from Macroevolution to Paleogeography. Berlin: Springer.

Kolis K. 2017. The biogeography and macroevolutionary trends of late Paleozoic cephalopods in the North American Midcontinent Sea: understanding the response of pelagic organisms to changing climate during the Late Paleozoic Ice Age. Master's Thesis, Department of Ecology \& Evolutionary Biology, University of Kansas. 
794 Korn D, Klug C. 2012. Paleozoic ammonoids - diversity and development of conch

795

796

797

798

799

800

801

802

803

804

805

806

807

808

809

810

811

812

813

814

815

816 morphology. In: Talent JA, ed. Earth and Life, International Year of Planet Earth. Berlin: Springer, 491-534.

Korn D, Klug C, Walton SA. 2015. Taxonomic diversity and morphological disparity of Paleozoic ammonoids. In: Klug C, Korn D, De Baets K, Kruta I, Mapes RH, eds. Ammonoid Paleobiology: from Macroevolution to Paleogeography. Berlin: Springer, 231-264.

Kröger B. 2005. Adaptive evolution in Paleozoic coiled cephalopods. Paleobiology 31:253-268.

Kröger B, Mapes RH. 2005. Revision of some common Carboniferous genera of North American orthocerid nautiloids. Journal of Paleontology 79:1002-1011.

Kullmann J. 1983. Maxima im tempo der evolution Karbonischer Ammonoideen. Paläontologische Zeitschrift 57:231-240.

Kullmann J. 1985. Drastic changes in Carboniferous ammonoid rates of evolution. In: Bayer U, Seilacher A, eds. Sedimentary and Evolutionary Cycles. Lecture Notes in Earth Sciences, vol. 1. Berlin: Springer, 35-47.

Kullmann J, Wagner RH, Winkler Prins CF. 2007. Significance for international correlation of the Perapertú Formation in northern Palencia, Cantabrian Mountains.

Tectonc/stratigraphic context and description of Mississippian and upper Bashkirian goniatites. Revista Española de Paleontología 22:127-145.

Kues BS. 1995. Marine fauna of the Early Permian (Wolfcampian) Robledo Mountains Member, Hueco Formation, southern Robledo Mountains, New Mexico. New Mexico Museum of Natural History and Science Bulletin 6:63-90.

Kummel B. 1953. American Triassic coiled nautiloids. U. S. Geological Survey Professional Paper 
250:1-149.

818 Kummel B. 1963. Miscellaneous nautilid type species of Alpheus Hyatt. Bulletin of the Museum of Comparative Zoology 128:325-368.

Lam AR, Stigall AL, Matzke N. 2018. Dispersal in the Ordovician: speciation patterns and 821 paleobiogeographic analyses of brachiopods and trilobites. Palaeogeography, Palaeoclimatology, Palaeoecology 489:147-165.

Landman N, Tanabe K, Davis RA, eds. 1996. Ammonoid Paleobiology. New York: Plenum.

824 Leighton LR. 2005. The latitudinal diversity gradient through deep time: testing the "Age of Tropics" hypothesis using Carboniferous productidine brachiopods. Evolutionary Ecology 19:563-581.

Liow LH. 2007. Does versatility as measured by geographic range, bathymetric range and morphological variability contribute to taxon longevity? Global Ecology and Biogeography 16:117-128.

Lieberman BS. 2000. Paleobiogeography: Using Fossils to Study Global Change, Plate Tectonics, and Evolution. New York: Kluwer Academic/Plenum.

Lieberman BS. 2002. Biogeography with and without the fossil record. Palaeogeography, Palaeoclimatology, Palaeoecology 178:39-52.

834 Lieberman BS, Kimmig J. 2018. Museums, paleontology, and a biodiversity science based approach. In: Rosenberg GD, Clary RM, eds. Museums at the Forefront of the History of Geology: History Made, History in the Making. Geological Society of America Special Paper 535. In press. https://doi.org/10.1130/2018.2535(22)

838 Lieberman BS, Melott AL. 2013. Declining volatility, a general property of disparate systems: 
from fossils, to stocks, to the stars. Palaeontology 56:1297-1304.

840

841

842

843

844

845

846

847

Marshall CR, Finnegan S, Clites EC, Holroyd PA, Bonuso N, Cortez C, Davis E, Dietl GP, Druckenmiller PS, Eng RC, Garcia C, Estes-Smargiassi K, Hendy A, Hollis KA, Little H, Nesbitt EA, Roopnarine P, Skibinski L, Vendetti J, White LD. 2018. Quantifying the dark data in museum fossil collections as palaeontology undergoes a second digital revolution. Biology Letters 14:20180431.

Mather KF. 1915. The fauna of the Morrow group of Arkansas and Oklahoma. Bulletin of Science Laboratories of Denison University 18:59-284.

Mayr E. 1942. Systematics and the Origin of Species. Cambridge: Harvard University Press.

McCaleb JA. 1963. The goniatite fauna from the Pennsylvanian Winslow Formation of northwest Arkansas. Journal of Paleontology 37:110-115.

McChesney AM. 1860. Descriptions of new species of fossils from the Paleozoic rocks of the western states. Transactions of the Chicago Academy of Sciences 1:1-76.

Meek FB, Worthen AH. 1860. Descriptions of new Carboniferous fossils from Illinois and other western states. Proceeding of the Academy of Natural Sciences of Philadelphia 4:447-472.

Meek FB, Worthen AH. 1870. Descriptions of new species and genera of fossils from the Palaeozoic rocks of the western states. Proceedings of the Academy of Natural Sciences of Philadelphia 22:22-56.

Mii HS, Grossman EL, Yancey TE. 1999. Carboniferous isotope stratigraphies of North America: implications for Carbonifeous paleoceanography and Mississippian glaciation. Geological Socity of America Bulletin 111:960-973. 
860 Miller AK. 1930. A new ammonoid fauna of Late Paleozoic age from western Texas. Journal of $861 \quad$ Paleontology 4:383-412.

862 Miller AK, Cline LM. 1934. The cephalopod fauna of the Pennsylvanian Nellie Bly Formation of $863 \quad$ Oklahoma. Journal of Paleontology 8:171-185.

864 Miller AK, Downs R. 1948. A cephalopod fauna from the type section of the Pennsylvanian 865 "Winslow Formation" of Arkansas. Journal of Paleontology 22:672-680.

Miller AK, Downs RH. 1950. Ammonoids of the Pennsylvanian Finis Shale of Texas. Journal of Paleontology 24:185-218.

Miller AK, Furnish WM. 1940a. Permian Ammonoids of the Guadalupe Mountain region and adjacent areas. Geological Society of America, Special Papers 26:1-238.

Miller AK, Furnish WM. 1940b. Studies of Carboniferous Ammonoids, Parts 5-7. Journal of Paleontology 14:521-543.

Miller AK, Furnish WM. 1957. Introduction to Ammonoidea. Pp. L1-L6 in W. J. Arkell et al., Part L Mollusca 4 Cephalopoda Ammonoidea. Treatise on Invertebrate Paleontology. Lawrence, Kansas: Geological Society of America.

Miller AK, Moore A, 1938. Cephalopods from the Carboniferous Morrow group of northern Arkansas and Oklahoma. Journal of Paleontology 22:341-354.

Miller AK, Owen JB. 1934. Cherokee nautiloids of the northern Mid-Continent region. University of Iowa Studies in Natural History 16:185-272.

Miller AK, Owen JB. 1937. A new Pennsylvanian cephalopod fauna from Oklahoma. Journal of Paleontology 11:403-422. 
881 Miller AK, Owen JB. 1939. An ammonoid fauna from the lower Pennsylvanian Cherokee

$882 \quad$ Formation of Missouri. Journal of Paleontology 13:141-162.

883 Miller AK, Thomas HD. 1936. The Casper Formation (Pennsylvanian) of Wyoming and its $884 \quad$ cephalopod fauna. Journal of Paleontology 10:715-738.

885 Miller AK, Unklesbay AG. 1942. Permian nautiloids from western United States. Journal of $886 \quad$ Paleontology 16:719-738.

887 Miller AK, Youngquist W. 1947. Lower Permian Cephalopods from the Texas Colorado River 888 Valley. The University of Kansas Paleontological Contributions 2:1-15.

889 Miller AK, Youngquist WL. 1949. American Permian nautiloids. Geological Society of $890 \quad$ America Memoir 41:1-217.

891 Miller AK, Dunbar CO, Condra GE. 1933. The nautiloid cephalopods of the Pennsylvanian 892 System in the Mid-continent region. Nebraska Geological Survey Bulletin 9:1-240.

893

894

895

896

897

898

899

900

901

Miller AK, Lane JH, Unklesbay AG. 1947. A nautiloid cephalopod fauna from the Pennsylvanian Winterset Limestone of Jackson Country, Missouri. University of Kansas Paleontological Contributions 2:1-11.

Miller AK, Youngquist W, Nielsen ML. 1952. Mississippian cephalopods from western Utah. Journal of Paleontology 26:148-161.

Miller HW, Breed WJ. 1964. Metacoceras bowmani, a new species of nautiloid from the Toroweap Formation (Permian) of Arizona. Journal of Paleontology 38:877-880.

Miller SA. 1892. Palaeontology. Geological Survey of Indiana Annual Report Advance Sheets 18.

Minitab 17 Statistical Software. 2016. State College, PA: Minitab, Inc. 
902 Monnet C, De Baets K, Klug C. 2011. Parallel evolution controlled by adaptation and 903 covariation in ammonoid cephalopods. BMC Evolutionary Biology 11:115, 1-21.

904 Montañez IP. 2007. $\mathrm{CO}_{2}$-forced climate and vegetational instability during Late Paleozoic 905 deglaciation. Science 315:87-91.

906 Montañez IP, Poulsen CJ. 2013. The late Paleozoic Ice Age: an evolving paradigm. Annual 907 Review of Earth Planet Science 41:629-656.

908 Myers CE, Lieberman BS. 2011. Sharks that pass in the night: using Geographical Information 909 Systems to investigate competition in the Cretaceous Interior Seaway. Proceedings of the Royal Society of London, Series B 278:681-689.

911 Myers CE, Saupe EE. 2013. A macroevolutionary expansion of the modern synthesis and the 912 importance of extrinsic abiotic factors. Palaeontology 56:1179-1198.

913 Myers CE, MacKenzie RA, Lieberman BS. 2013. Greenhouse biogeography: the relationship

914 of geographic range to invasion and extinction in the Western Interior Seaway.

$915 \quad$ Paleobiology 39:135-148.

916 Nassichuk WW. 1975. Carboniferous ammonoids and stratigraphy in the Canadian Arctic 917 archipelago. Geological Survey of Canada Bulletin 237:1-240.

918 Nelson WJ, Lucas SG. 2011. Carboniferous geologic history of the Rocky Mountain region. 919 New Mexico Museum of Natural History and Science Bulletin 53:115-142.

920 Newell ND. 1936. Some mid-Pennsylvanian invertebrates from Kansas and Oklahoma: III. 921 Cephalopoda. Journal of Paleontology 10:481-489. 
922 Niko S, Mapes RH. 2009. Redescription and new information on the Carboniferous cephalopod

923

924

925

926

927

928

929

930

931

932

933

934

935

936

937

938

939

940

941

942

943 Brachycycloceras normale Miller, Dunbar and Condra, 1933. Paleontological Research 13:337-343.

Orzechowski EA, Lockwood R, Byrnes JEK, Anderson SC, Finnegan S, Finkel ZV, Harnik PG, Lindberg DR, Liow LH, Lotze HK, McClain CR, McGuire JL, O'Dea A, Pandolfi JM, Simpson C, Tittensor D. 2015. Marine extinction risk shaped by trait-environment interactions over 500 million years. Global Change Biology 21:35953607.

Payne JL, Finnegan S. 2007. The effect of geographic range on extinction risk during background and mass extinction. Proceedings of the National Academy of Sciences, USA 104:10506-10511.

Pie MR, Meyer ALS. 2017. The evolution of range sizes in mammals and squamates: heritability and differential evolutionary rates for low- and high-latitude limits. Evolutionary Biology 44:347-355.

Plummer FB, Scott G. 1937. Upper Paleozoic ammonites of Texas: the geology of Texas. University of Texas Bulletin 3701, vol 3, part 1:1-516.

Pope JP. 2012. Description of Pennsylvanian units, revision of stratigraphic nomenclature and reclassification of the Morrowan, Atokan, Desmoinesian, Missourian, and Virgilian stages in Iowa. Iowa Department of Natural Resources Special Report Series 5:1-140.

Powell MG. 2005. Climatic basis for sluggish macroevolution during the late Paleozoic ice age. Geology 33:381-384.

Powell MG. 2007. Latitudinal diversity gradients for brachiopod genera during late Paleozoic 
944

945

946

947

948

949

950

951

952

953

954

955

956

957

958

959

960

961

962

963

964

965

time: links between climate, biogeography and evolutionary rates. Global Ecology and Biogeography 16:519-528.

R version 3.4.0. 2017. You Stupid Darkness. Vienna, Austria: R foundation for statistical computing.

Ramsbottom WHC. 1981. Eustatic control in Carboniferous ammonoid biostratigraphy. In: House MR, Senior JR, eds. The Ammonoidea, Systematics Association Special Volume 18. London: Academic Press, 369-398.

Raymond A, Metz C. 2004. Ice and its consequences: glaciation in the Late Ordovician, Late Devonian, Pennsylvanian-Permian and Cenozoic compared. Journal of Geology 112:655670.

Rios NE, Bart HL Jr. 2018. GEOlocate: a platform for georeferencing natural history collections data. https://www.geo-locate.org .

Ritterbush KA, Hoffmann R, Lukender A, De Baets K. 2014. Pelagic palaeoecology: the importance of recent constraints on ammonoid palaeobiology and life history. Journal of Zoology 292:229-241.

Roark A, Flake R, Grossman EL, Olszewski T, Lebold J, Thomas D, Marcantonio F, Miller B, Raymond A, Yancey T. 2017. Brachiopod geochemical records from across the Carboniferous seas of North America: evidence for salinity gradients, stratification, and circulation patterns. Palaeogeography, Palaeoclimatology Palaeoecology 485:136-153.

Rode AL, Lieberman BS. 2004. Using GIS to unlock the interactions between biogeography, environment, and evolution in Middle and Late Devonian brachiopods and bivalves. Palaeogeography, Palaeoclimatology, Palaeoecology 211:345-359. 
966 Rode AL, Lieberman BS. 2005. Intergrating evolution and biogeography: a case study

967 involving Devonian crustaceans. Journal of Paleontology 79:267-276.

968

969

970

971

972

973

974

975

976

Rojas A, Patarroyo P, Mao L, Bengtson P, Kowalewski M. 2017. Global biogeography of Albian ammonoids: a network-based approach. Geology 45:659-662.

Rook DL, Heim NA, Marcot J. 2013. Contrasting patterns and connections of rock and biotic diversity in the marine and non-marine fossil records of North America. Palaeogeography, Palaeoclimatology, Palaeoecology 372:123-129.

Rothwell Group LP. 2016. PaleoWeb: Free Plate Tectonics Software. Lakewood, CO.

Ruzhentsev VE, Bogoslovskaya MF. 1971. Namurskiy etap v evolyutsii ammonoidey. Rannenamyurskie ammonoidei. Akademiya Nauk SSSR, Trudy Paleontologicheskogo Instituta 133:1-382.

Ruzhentsev VE, Shimanskiy VN. 1954. Nizhnepermskie svernutye i sognutye Nautiloidei yuzhnogo Urala. Akademiya Nauk SSSR, Trudy Paleontologicheskogo Instituta 50:1-150.

Saupe EE, Qiao H, Hendricks JR, Portell RW, Hunter SJ, Soberón J, Lieberman BS. 2015. Niche breadth and geographic range size as determinants of species survival on geological time scales. Global Ecology and Biogeography 24:1159-1169.

Sawin RS, West RR, Franseen EK, Watney WL, McCauley JR. 2006. CarboniferousPermian boundary in Kansas, midcontinent, USA: current research in earth sciences. Kansas Geological Survey, Bulletin 252, Part 2:1-13.

Sawin RS, Franseen EK, West RR, Ludvigson GA, Watney WL. 2008. Clarification and changes in Permian stratigraphic nomenclature in Kansas: current research in earth sciences. Kansas Geological Survey, Bulletin 254, Part 2:1-4. 
988 Sawin RS, Franseen EK, Watney WL, West RR, Ludvigson GA. 2009. New stratigraphic 989 rank for the Carboniferous, Mississippian, and Pennsylvanian in Kansas: current research in earth sciences. Kansas Geological Survey, Bulletin 256, Part 1:1-4.

991 Sayre AN. 1930. The fauna of the Drum Limestone of Kansas and western Missouri. University of 992 Kansas Science Bulletin 19:1-203

993

994

995

996

997

Schneider CL. 2018. Marine refugia past, present, and future: lessons from ancient geologic crises for modern marine ecosystem conservation. In: Tyler CL, Schneider CL, eds.. Marine Conservation Paleobiology. Berlin: Springer, 163-208.

Segessenman DC, Kammer TW. 2018. Testing evolutionary rates during the late Paleozoic ice age using the crinoid fossil record. Lethaia 51:330-343.

Sepkoski JJ Jr. 1998. Rates of speciation in the fossil record. Philosophical Transactions of the Royal Society of London 353:315-326.

\section{Simões M, Breitkreuz L, Alvarado M, Baca S, Cooper JC, Heins L, Herzog K, Lieberman} BS. 2016. The evolving theory of evolutionary radiations. Trends in Ecology and Evolution (TREE) 31:27-34.

Smith HJ. 1938. The Cephalopod Fauna of the Buckhorn Asphalt. Chicago: University of Chicago Libraries.

Smith JP. 1896. Marine fossils from the Coal Measures of Arkansas. Proceedings of the American Philosophical Society 35:213-285.

Smith JP. 1903. The Carboniferous ammonoids of America. Monographs of the United States Geological Survey 52:1-211.

Sokal RR, Rohlf FJ. 1994. Biometry: the Principles and Practices of Statistics in Biological 
1011 Stanley SM. 1979. Macroevolution. San Francisco: W. H. Freeman.

1012 Stanley SM. 1990. The general correlation between rate of speciation and rate of extinction:

1013 fortuitous causal linkages. In: Ross RM, Allmon WD, eds. Causes of Evolution: $a$

1014 Paleontological Perspective. Chicago: University of Chicago Press, 103-127.

1015 Stanley SM, Powell MG. 2003. Depressed rates of origination and extinction during the late

1016 Paleozoic ice age: a new state for the global marine ecosystem. Geology 31:877-880.

1017 Stigall AL. 2010. Using GIS to assess the biogeographic impact of species invasions on native 1018 brachiopods during the Richmondian Invasion in the type-Cincinnatian (Late Ordovician, 1019 Cincinnati region). Palaeontologia Electronica 13(1), 5A:1-19.

1020 Stigall AL, Lieberman BS. 2006. Quantatative palaeobiogeography: GIS, phylogenetic biogeographical analysis and conservation insights. Journal of Biogeography 33:20512060.

Sturgeon MT. 1946. Allegheny fossil invertebrates from eastern Ohio-Nautiloidea. Journal of Paleontology 20:8-37.

Sturgeon MT, Windle DL, Mapes RH, Hoare RD. 1982. New and revised taxa of Pennsylvanian cephalopods in Ohio and West Virginia. Journal of Paleontology 56:1453-1479.

Swallow GC. 1858. Rocks of Kansas with descriptions of new Permian fossils. Transactions of the Academy of Sciences St. Louis 1:1-27.

Tabor NJ. 2007. Permo-Pennsylvanian palaeotemperatures from Fe-Oxide and phyllosilicate ¿O18 values. Earth and Planetary Science Letters 253:159-171. 
1031 Tabor NJ, Poulsen CJ. 2007. Paleoclimate across the late Pennsylvanian-early Permian tropical

1032

1033

1034

1035

1036

1037

1038

1039

1040

1041

1042

1043

1044

1045

1046

1047

1048

1049

1050

1051

paleolatitudes: a review of climate indicators, their distribution, and relation to palaeophysiographic climate factors. Palaeogeography, Palaeoclimatology, Palaeoecology 268:293-310.

Teichert C. 1940. Contributions to nautiloid nomenclature. Journal of Paleontology 14:590-597.

Teichert C, Kummel B, Sweet WC, Stenzel HB, Furnish WM, Glenister BF, Erben HK, Moore RC, Zeller D. 1964. Part K Mollusca 3 Cephalopoda-General Features, EndoceratoideaActinoceratoidea-Nautiloidea-Bactritoidea. Treatise on Invertebrate Paleontology. Lawrence, Kansas: The Geological Society of America.

Unklesbay AG. 1954. Distribution of American Pennsylvanian cephalopods. Journal of Paleontology 28:84-95.

Unklesbay AG, Palmer EJ. 1958. Cephalopods from the Burgner Formation in Missouri. Journal of Paleontology 32:1071-1076.

US Geological Survey. 2017. U.S. Geologic Names Lexicon ("Geolex"). Retrieved from the National Geologic Map Database: https://ngmdb.usgs.gov/Geolex/search .

Vrba ES. 1980. Evolution, species, and fossils: how does life evolve? South African Journal of Science 76:61-84.

Vrba ES. 1987. Ecology in relation to speciation rates: some case histories of Miocene-Recent mammal clades. Evolutionary Ecology 1:283-300.

Ward PD, Westermann GEG. 1985. Cephalopod paleoecology. Studies in Geology, Notes for a Short Course (Mollusks) 13:215-229. 
1052 Waterhouse JB, Shi GR. 2010. Late Palaeozoic global changes affecting high-latitude

1053 environments and biotas: an introduction. Palaeogeography, Palaeoclimatology,

1054 Palaeoecology 298:1-16.

1055 Wells MR, Allison PA, Piggott MD, Gorman GJ, Hampson GJ, Pain CC, Fang F. 2007.

1056 Numerical modeling of tides in the late Pennsylvanian Midcontinent Seaway of North

1057 America with implications for hydrography and sedimentation. Journal of Sedimentary

$1058 \quad$ Research 77:843-865.

1059 White CA. 1889. On the Permian formation of Texas. The American Naturalist 23:109-128.

1060 White CA, St. John OH. 1867. Descriptions of new Subcarboniferous and Coal Measure fossils

1061 collected upon the Geological Survey of Iowa; together with a notice of new generic

1062 characters observed in two species of brachiopods. Transactions of the Chicago Academy of

1063 Sciences 1:115-127.

1064 White RD, Skorina LK. 1999. A type catalog of fossil invertebrates (Mollusca: Actinoceratoiclea,

1065 Bactritoidea, Endoceratoidea, and Nautiloidea) in the Yale Peabody Museum. Postilla 219:1-

106639.

1067 Wieczorek C, Wieczorek J. 2015. Georeferencing calculator (version 20160920). Museum of

1068 Vertebrate Zoology, University of California, Berkeley. http://manisnet.org/gci2.html .

1069 Wiedmann J, Kullmann J. 1996. Crises in ammonoid evolution. In: Landman NH, Tanabe K,

1070 Davis RA, eds. Ammonoid Paleobiology. Boston: Springer, 795-813.

1071 Wiley EO, Lieberman BS. 2011. Phylogenetics, $2^{\text {nd }}$ edition. New York: J. Wiley \& Sons.

1072 Yacobucci MM. 2017. Marine life in a greenhouse world: cephalopod biodiversity and

1073 biogeography during the early Late Cretaceous. Paleobiology 43:587-619.

1074 Young JA. 1942. Pennsylvanian Scaphopoda and Cephalopoda from New Mexico. Journal of 
1075 Paleontology 16:120-125.

1076 Zeller DE, ed. 1968. The stratigraphic succession in Kansas. Kansas Geological Survey, Bulletin $1077 \quad$ 189:1-81.

1078 Zhang M, Becker RT, Ma X, Zhang Y, Zong. 2019. Hangenberg Black Shale with 1079 cymaclymeniid ammonoids in the terminal Devonian of South China. Palaeobiodiversity 1080 and Palaeoenvironments. In press. https://doi.org/10.1007/s12549-018-0348-x

1081

1082

1083

1084

1085

1086

1087

1088

1089

1090

1091

1092

1093 
1094 Figure Captions

1095

1096 Figure 1: Distribution of Pennsylvanian and early Permian cephalopods.

1097 A) Distribution of Pennsylvanian nautiloid and ammonoid data points (red) and B) early Permian

1098 nautiloid and ammonoid data points (blue) across the midcontinent region of North America.

1099 Plotted using ArcGIS v. 10.3 (ESRI, 2014) software at 1: 20,000,000.

1101 Figure 2: Occurrence points of Metacoceras sp. and Mooreoceras sp.

1102 For the Virgilian, shown on possible paleogeography of that stage, at 1:1,000,000,000 scale;

1103 plotted using PaleoWeb (The Rothwell Group LP, 2016).

1104

1105 Figure 3: Mean geographic range size in $\mathbf{k m}^{\mathbf{2}}$ of cephalopods through time.

1106 Nautiloid species (A) and ammonoid species (B) range changes occur but are not statistically

1107 significant when analyzed using non-parametric tests (note, median range size data not graphed

1108 but for all cephalopods they are $79 \mathrm{~km}^{2}$ for all time intervals, for ammonoids they are $78.5 \mathrm{~km}^{2}$ for

1109 the Desmoinesian and Wolfcampian and $79 \mathrm{~km}^{2}$ for all other time intervals, and for nautiloids

1110 they are $79 \mathrm{~km}^{2}$ for all time intervals) or when log transformed data are analyzed using

1111 parametric tests (note log transformed data not graphed but mean transformed values for all

1112 cephalopods are 5.51 [standard error 0.75] for the Morrowan, 4.05 [standard error 1.02] for the

1113 Atokan, 4.36 [standard error 0.49] for the Desmoinesian, 5.65 [standard error 0.49] for the

1114 Missourian, 5.96 [standard error 0.79] for the Virgilian, and 4.31 [standard error 0.52] for the

1115 Wolfcampian). 
1116

1117 Figure 4: Speciation and extinction rates through time.

1118 Values given in per Myr and derived from Table 1. 


\section{Table $\mathbf{1}$ (on next page)}

Speciation rates (S) per millions of years (Myr), extinction rates (E) per Myr, and rate of turnover (R) per Myr, for each stage across all cephalopods.

Species richness values, species carryover from the previous stage, new species originating in the stage, $\mathrm{N}_{\mathrm{o}}$ (the initial number of species), $\mathrm{N}_{\mathrm{f}}$ (the final number of species), and duration (in Myr) also given. 
1 Table 1:

2 Speciation rates (S) per millions of years (Myr), extinction rates (E) per Myr, and rate of 3 turnover (R) per Myr, for each stage across all cephalopods, with species richness values, 4 species carryover from the previous stage, new species originating in the stage, $N_{0}$ (the 5 initial number of species), $\mathbf{N}_{\mathbf{f}}$ (the final number of species), and duration (in Myr) also 6 given.

\begin{tabular}{|l|r|r|r|r|r|r|r|r|r|}
\hline Stage & $\begin{array}{c}\text { Species } \\
\text { Richness }\end{array}$ & $\begin{array}{c}\text { Species } \\
\text { Carryover }\end{array}$ & $\begin{array}{c}\text { New } \\
\text { Species }\end{array}$ & $\mathbf{N}_{\mathbf{o}}$ & $\mathbf{\mathbf { N } _ { \mathbf { f } }}$ & Duration & $\mathbf{R}$ & $\mathbf{S}$ & $\mathbf{E}$ \\
\hline Wolfcampian & 13 & 7 & 6 & 7 & 13 & 14 & & 0.0442 & \\
\hline Virgilian & 38 & 32 & 6 & 32 & 38 & 5 & -0.3040 & 0.0343 & 0.3383 \\
\hline Missourian & 55 & 33 & 22 & 33 & 55 & 3 & -0.0103 & 0.1703 & 0.1805 \\
\hline Desmoinesian & 41 & 12 & 29 & 12 & 41 & 3 & 0.3372 & 0.4096 & 0.0724 \\
\hline Atokan & 15 & 7 & 8 & 7 & 15 & 2 & 0.2694 & 0.3811 & 0.1116 \\
\hline Morrowan & 8 & 0 & 8 & 0 & 8 & 6 & & & \\
\hline
\end{tabular}

9 


\section{Table 2 (on next page)}

Pearson correlation test for association between $\mathrm{S}$ and geographic range and $\mathrm{E}$ and geographic range across all cephalopods and for ammonoids and nautiloids individually.

Pearson's $r$ and P-values given. 
1 Table 2:

2 Pearson correlation test for association between $S$ and geographic range and $E$ and

3 geographic range across all cephalopods and for ammonoids and nautiloids individually, 4 with Pearson's $r$ and P-values given.

5

\begin{tabular}{|l|r|r|l|r|r|}
\hline Taxon - Speciation & Pearson's r & P-value & Taxon - Extinction & Pearson's r & \multicolumn{1}{|l|}{ P-value } \\
\hline All Cephalopods - S & -0.541 & 0.347 & All Cephalopods - E & 0.925 & 0.075 \\
\hline Nautiloids- S & -0.463 & 0.432 & Nautiloids - E & 0.913 & 0.087 \\
\hline Ammonoids - S & -0.519 & 0.370 & Ammonoids - E & 0.803 & 0.197 \\
\hline
\end{tabular}

6 
Figure 1

Distribution of Pennsylvanian and early Permian cephalopods.

A) Distribution of Pennsylvanian nautiloid and ammonoid data points (red) and B) early

Permian nautiloid and ammonoid data points (blue) across the midcontinent region of North America. Plotted using ArcGIS v. 10.3 (ESRI, 2014) software at 1: 20,000,000.
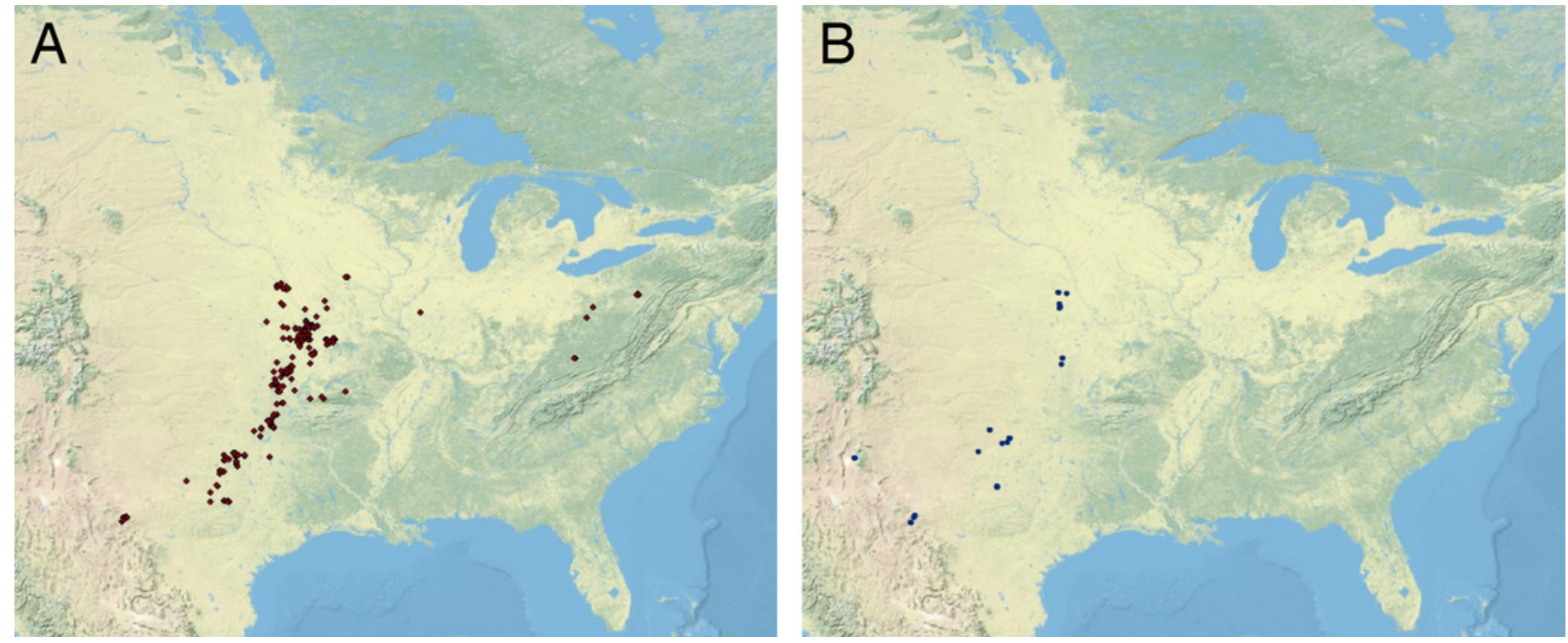
Figure 2

Occurrence points of Metacoceras sp. and Mooreoceras sp.

For the Virgilian, shown on possible paleogeography of that stage, at 1:1,000,000,000 scale; plotted using PaleoWeb (The Rothwell Group LP, 2016).

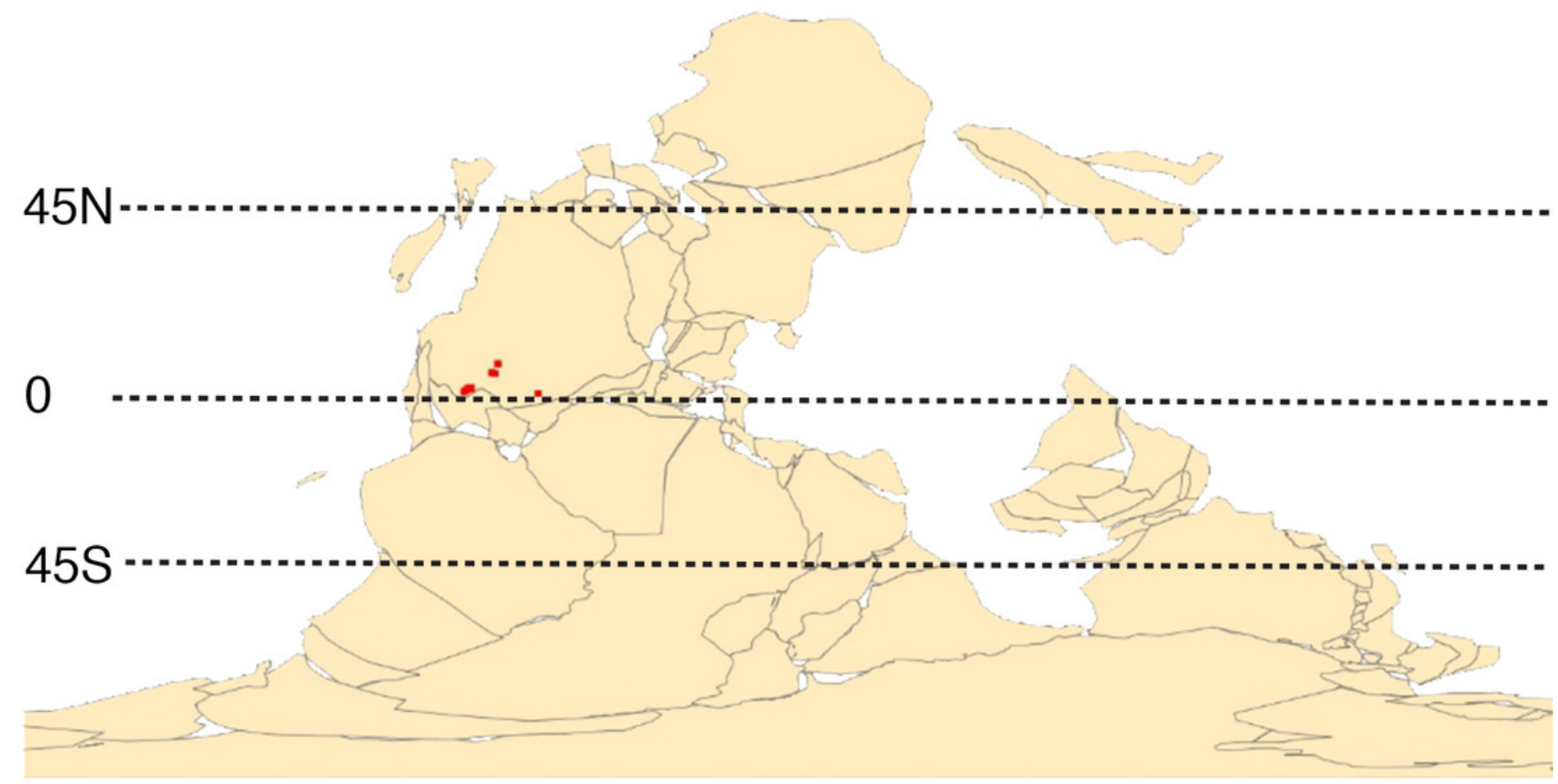


Figure 3

Mean geographic range size in $\mathrm{km}^{2}$ of cephalopods through time.

Nautiloid species (A) and ammonoid species (B) range changes occur but are not statistically significant when analyzed using non-parametric tests (note, median range size data not

graphed but for all cephalopods they are $79 \mathrm{~km}^{2}$ for all time intervals, for ammonoids they are $78.5 \mathrm{~km}^{2}$ for the Desmoinesian and Wolfcampian and $79 \mathrm{~km}^{2}$ for all other time intervals, and for nautiloids they are $79 \mathrm{~km}^{2}$ for all time intervals) or when log transformed data are analyzed using parametric tests (note log transformed data not graphed but mean transformed values for all cephalopods are 5.51 [standard error 0.75] for the Morrowan, 4.05 [standard error 1.02] for the Atokan, 4.36 [standard error 0.49] for the Desmoinesian, 5.65 [standard error 0.49] for the Missourian, 5.96 [standard error 0.79] for the Virgilian, and 4.31 [standard error 0.52] for the Wolfcampian).

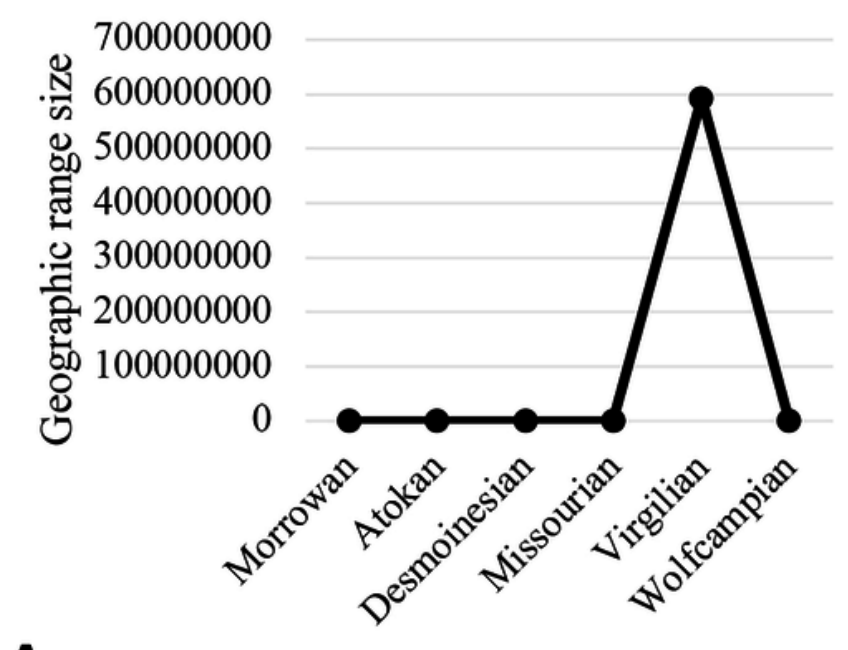

A

Temporal stage

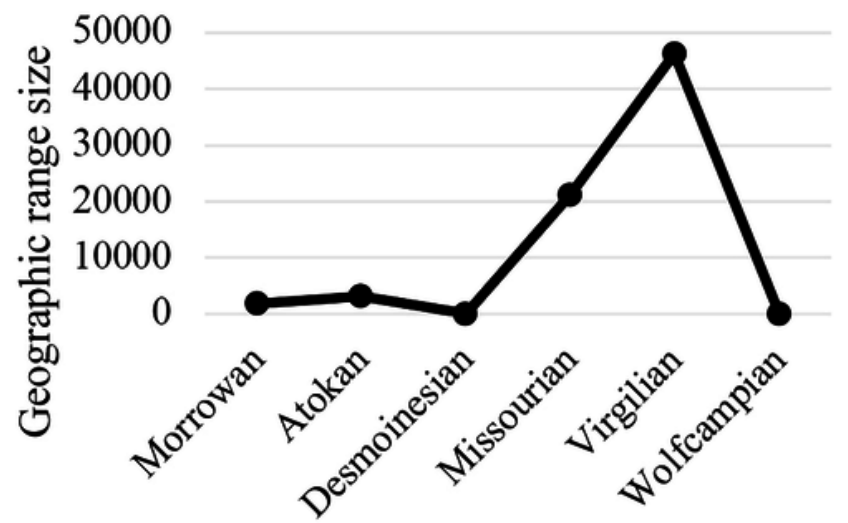

Temporal stage 
Figure 4

Speciation and extinction rates through time.

Values given in per Myr and derived from Table 1.

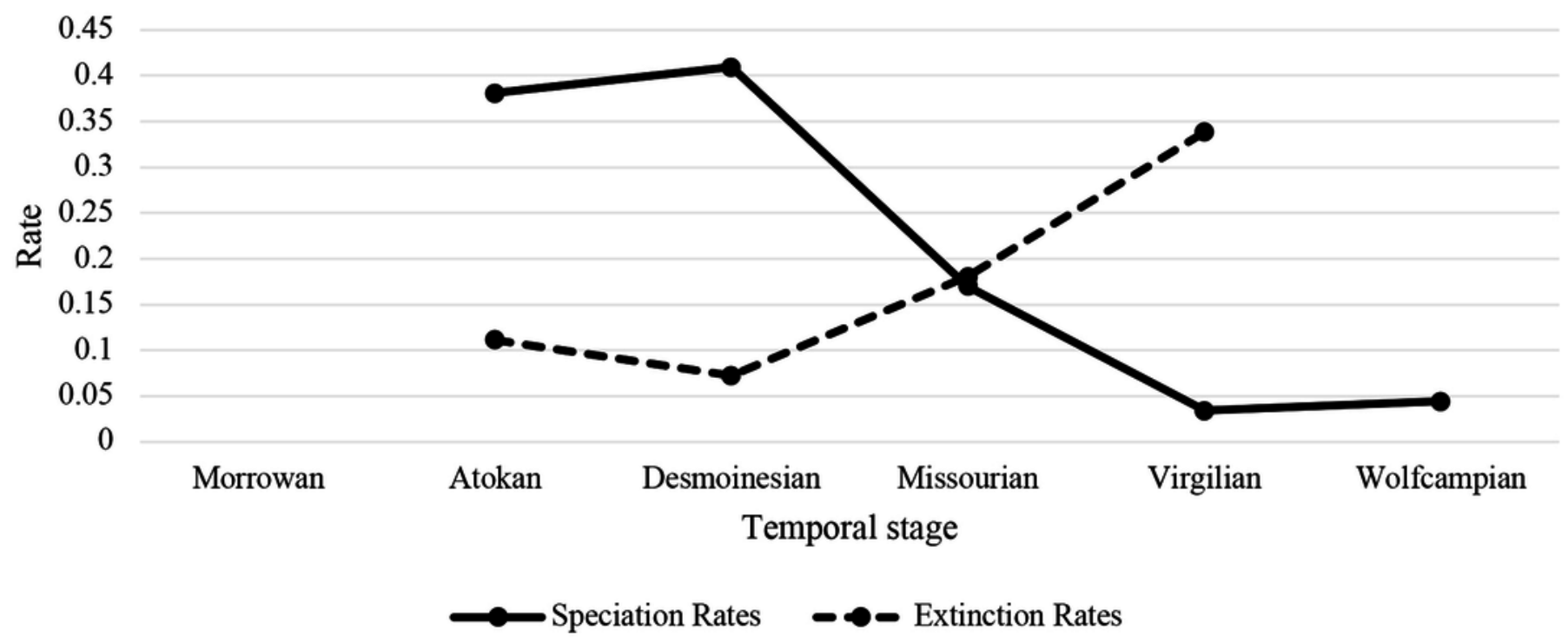

